\title{
POTIERY IN THE COLLECTION OF THE COOPER-HEWITT MUSEUM
}







\section{Pottery}

NK

3730

N5C778 CHM

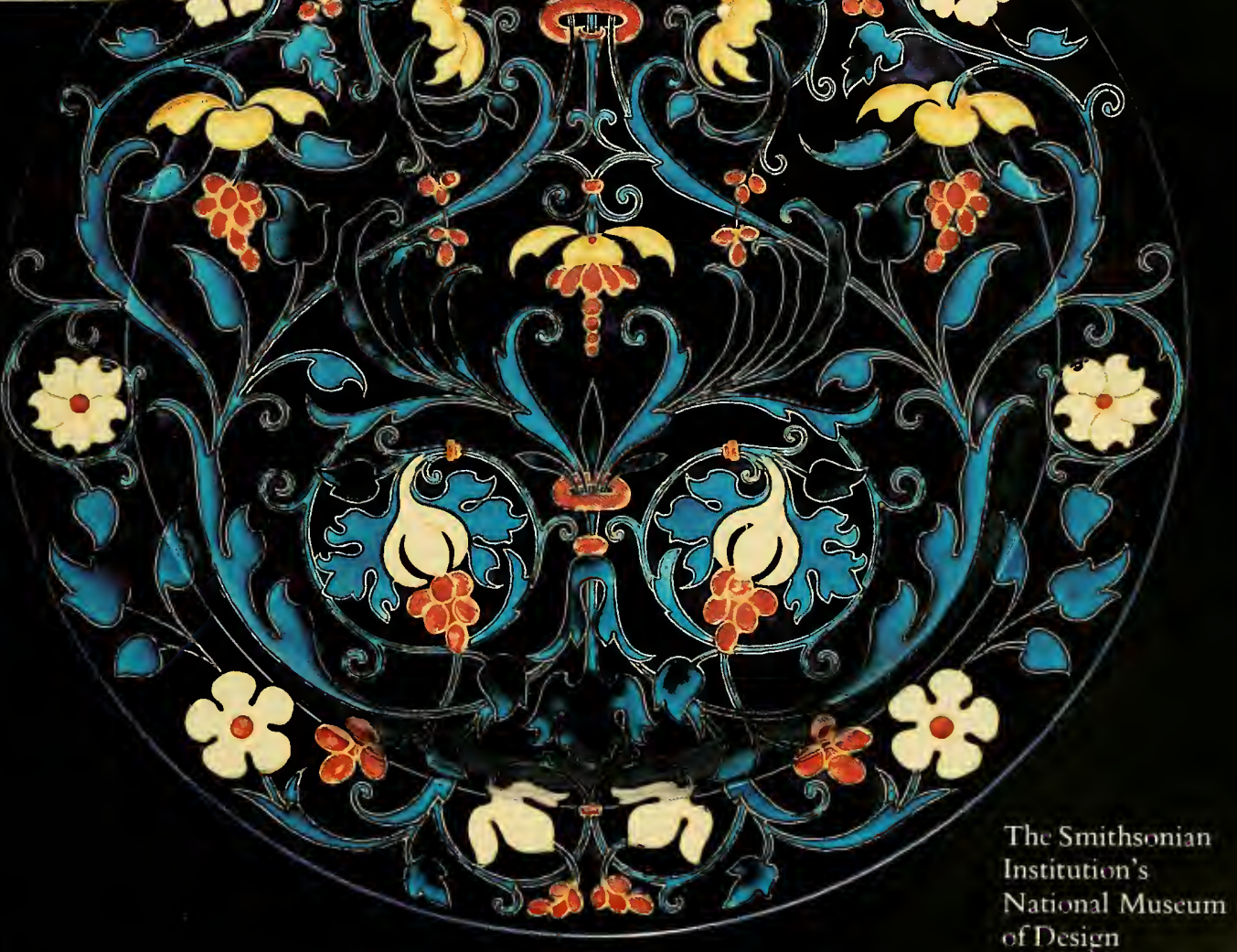





\section{Pottery}

in the Collection of the

Cooper-Hewitt Museum

102

3730

N5C778

CHMI

The Smithsonian Institution's

National Museum of Design 
front cover:

Théodore Deck (1823-1891)

France

Platter, about 1870

Earthenware, enamel decoration

Gift of Eleanor Hewitt

1931-40-37

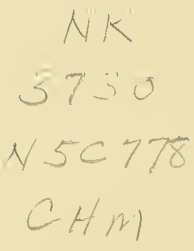

Photographs by Tom Rose

Designed by Heidi Humphrey

Printed by Eastern Press, Inc.

Typeset by Trufont Typographers, Inc.

(C) 1981 by The Smithsonian Institution

All rights reserved

Library of Congress Catalog No. 81-67381 
Of all the collections within the Cooper-Hewitt Museum that contain objects representing a wide range of times, places, and traditions, pottery is undoubtedly among the most diverse and encylopedic. This is due in part to the fact that nearly all cultures, from prehistoric times to the present, have produced some form of pottery-be it humble utilitarian earthenware, radiant polychromed tin-glazed wares, or lustrous and elegant stonewares. The variety of forms and the modes of decoration that can be studied in the history of pottery make it one of the most pertinent to the continuing development of design.

The collection of pottery at the Museum represents the tastes, interest, and knowledge of many individual donors who have added important examples over the decades since the founding of the Museum. Early additions to the collection included numerous examples of the pottery traditions of eighteenth-century Continental Europe and England; these core collections were soon buttressed by pertinent examples that represented the traditions of the Middle East, the
Orient, and the Americas. During the past two decades there has been a concerted effort to expand the collection to include primary examples of the work of nineteenth-and twentieth-century potters, studios, and factories. The collection continues to grow in both historic and contemporary pottery according to the collecting policies established by the Museum.

The complex history of pottery surveyed in this catalogue links the objects to the aesthetic and practical concerns of the societies that created, used, and enjoyed them. The Cooper-Hewitt collection, as it develops in both quality and quantity, will serve as a primary resource for those who share our interest in this vital field of design. We are deeply grateful to Janet Annenberg Hooker for having made this publication possible.

\section{Lisa Taylor \\ Director}


Civilization may be considered the record of man's continuing relationship with the natural and social environment, encompassing aspects of human life from the pragmatic to the spiritual. There are many artifacts that serve as cultural documents of this relationship, and these comprise the raw material of history. Although fundamental stages in social organization - the domestication of animals and the systematic propagation of foodstuffs - provide a dramatic record of the process of civilization, few early artifacts documenting the creative maturation of mankind have the evocative power of a humble piece of pottery. In a sense pottery may be considered a tool, in that it serves specific and practical functions; it may, however, also be viewed as a means of aesthetic expression that encompasses a broader spectrum of functions, including those of ceremony and ritual.

Pottery, both utilitarian and ceremonial, appeared extremely early in a large number of prehistoric cultures and rapidly became indispensable to man. Archaeological finds have indicated that a pottery tradition can be documented during the late Ice Age, and from this early date to the present virtually every culture that has had access to clay and has had the technological sophistication to use it has manufactured some variety of pottery; the types, forms, and decorations are seemingly unlimited, often distinctive in appearance, and frequently consonant with the more general aesthetic concerns of the society in which it is produced. It is this documentary role, as a recorder of culture, that makes the study of pottery so important to an understanding of history.

Within most cultures, pottery is used primarily for performing practical tasks, and suitability to serve a particular function is usually a prerequisite of the design. Pottery has always been especially useful for storing, preparing, and serving food and drink. The utilitarian role of a piece of pottery is rarely seen in isolation, however, since the medium also records a human aesthetic response to form and decoration. The manipulation of clay is a formative gesture, and the object that results has a meaning that transcends function alone. It is the human ability 
to "form" as well as to "shape" that gives pottery a particular vitality as a means of aesthetic expression.

The making of any ceramics - be it earthenware, stoneware, or porcelain-depends on clay, a natural material that results from the gradual decomposition of stones. Chemically, the material may be simple or complex, common or rare, depending upon available local sources and the choice of the potter. Clay may be turned into pottery in a variety of ways and through the use of a variety of tools and implements. Essential to pottery fabrication is a means of hardening the soft clay, generally through exposure of the formed object to some type of heat. These two processesforming and firing - remain constants throughout the history of the craft and deserve an introductory coverage.

To be workable, clay must be combined with water; once the potter has finished working the clay, this water must be removed in order to produce a solid, shape-retaining form. Most water may be removed by simply allowing the clay to dry, but to insure that the water has been thoroughly eliminated, a heating process known as firing is used. Firing may take place in several ways: placing a pot or clay object in a fire or within the glowing coals of a fire and covering it to trap the heat will result in a kind of firing. More common, however, is the use of a specially designed and constructed oven, called a kiln, in which the pottery is exposed to a high, constant, and controlled heat without being in direct contact with flames. This sophisticated tool is known to have been in operation before 4000 B.C. in certain Persian and Mesopotamian pottery centers. Many of the techniques and tools of the crafț, including the kiln, were undoubtedly disseminated by migrating peoples, but they were also probably invented independently in societies that had no direct contact with each other. Such advances, whether innovations or borrowings, reflect the rapid intellectual strides made in many prehistoric and protohistoric cultures.

A vessel or object of clay can be formed in several different ways, each of which requires a different level of technical proficiency. The simplest manipulation of clay is done by applying hand-pressure to a lump or mass of clay in order to create a concave depression. Continued pinching or squeezing of the clay eventually produces a simple hollow form. A more sophisticated technique is known as building, in which a progressive addition of coils or pieces of clay around a hollow core creates a form. Built pots depend on the ability of clay to adhere to itself and to remain intact through pressure. By far the most prevalent and familiar technique is that of wheelthrowing, in which an unformed mass of clay is rotated on a flat surface. Shaping occurs as a result of applying exterior and interior hand pressure to the rotating mass. This causes the clay to rise, spread, increase or decrease in thickness, and arrive at a consistent, hollow, three-dimensional form.

Although numerous other refinements in technique are known to potters, an alternative to wheel-throwing is molding, in which the moist clay is pressed into a non-resilient shaping device or mold. The plasticity of the clay causes it to assume and retain the 
reverse or "negative" shape of the mold; if the mold is created as a negative shape, the clay will emerge as a "positive" form. An extension of this technique involves pouring semiliquid clay (called slip) into an absorbent removable mold; when sufficient water has been drawn from this mixture a firm semi-dry shape can be extracted from the mold.

Formed and dried clay vessels, even when fired, may not be impermeable to liquids. The basic ways of preventing absorption of liquids have been known to potters for centuries. Clays that contain decomposed fusible materials, such as feldspar, may be fired to a temperature that causes the clay to fuse to a degree that renders it impermeable to water. Such high-fired and more completely fused clay bodies are known as stonewares. The most refined ceramic body-porcelain-is also the most nearly perfectly fused, its appearance achieving a translucency that resembles glass more closely than clay.

The second, and by far the oldest, method of producing a water-tight surface on a pottery vessel is through the application of a powdered vitreous substance, which, under heat, will melt to form a glassy coating that adheres to the clay. Such a coating is known as a glaze. In addition to their functional importance, glazes offer a myriad of ornamental possibilities, since they may contain brilliant color. Potters have relied upon the decorative potential of glazes for centuries, and the variety of glazing methods and styles contributes to the rich panorama of pottery history.

The forms and decoration of pottery surveyed in this catalogue, all of which are illustrated by examples from the permanent collection of the CooperHewitt Museum, are so varied that major types can only be suggested. It is worthwhile to examine typical examples of the more significant schools, studios, and artists who have contributed to the history of the craft. Selections range from the tenth century B.C. to the present decade, and include both earthenware and stoneware, although not porcelain, a related but distinct area of ceramic history.
A rchaeological evidence indicates that potters were working at prehistoric sites in Moravia as early as 4000 B.C. Between then and about the tenth century B.C., when the oldest piece of pottery in the Cooper-Hewitt collection was made, many generations of potters were born, created their works, and disappeared, leaving behind the documents of their creativity. The potter responsible for the Cooper-Hewitt's piece-an elegant flared bowl found in Necropolis B at Syalk in Persia (Figure 1) - is anonymous, although the form and decoration of the piece clearly indicate its origin. The tapered base of the bowl and the delicately profiled upper body reveal a sensitive perception of form.

Potters throughout history have created their designs in concert with larger general design movements within a society, and this bowl offers a visual discourse on the symbolism of the period. In addition to the general form, the painting style is typical; the matte brown paint used on the pot is common to much Persian pottery of the period. The design includes standing ibexes whose horns encircle a 
stylized representation of the sun; these passages are separated by panels of checkerboard pattern. In addition to having symbolic content, the designs form a coherent repeat pattern. This repetition of designs around the continuous form visually connotes a grander philosophical continuity, a meaning implicit in the repetition of motifs. The use of the pottery form as a canvas on which visual information may be painted was, and still is, an important aspect of the design vocabulary within the history of the art.

Nearly five hundred years later in date than this Persian bowl is a Greek kylix, or two-handled drinking vessel (Figure 2) from the mid-sixth century B.C. Greek pottery has long been admired for its elegant and distinctive forms, but even more so for its superb figural decoration. The CooperHewitt kylix was shaped on a wheel, a technique that had appeared in the Greek world by the beginning of the second millennium B.C. It is decorated in the "black-figure" technique, in which glossy black figures are painted over a rich red-brown ground; often these figures are inscribed with fine

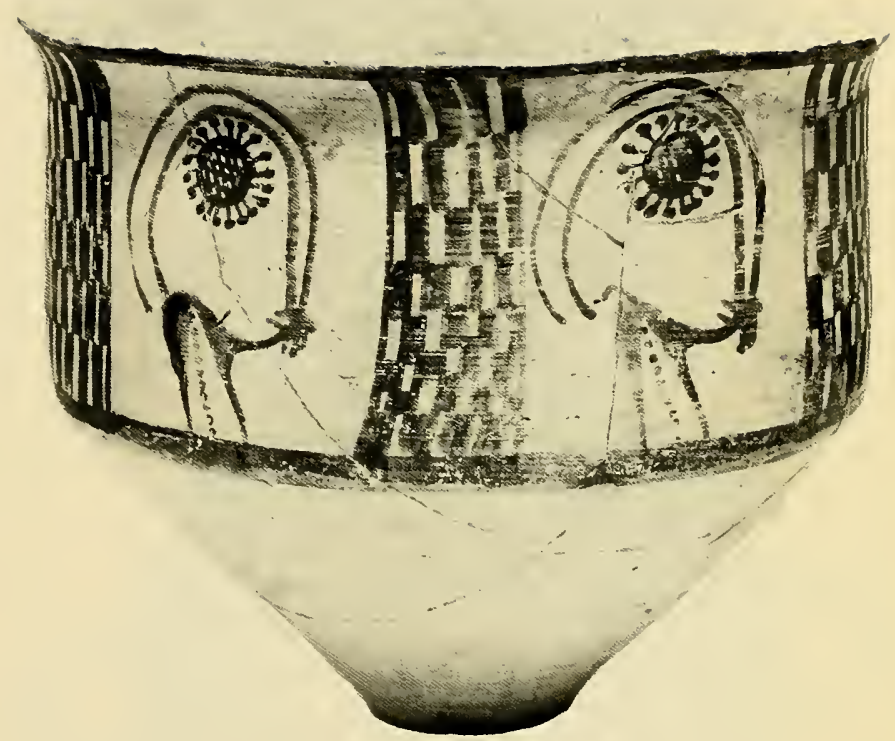

1.

Persia, Syalk

Deep Bowl, 11th-10th century B C. or earlier

Unglazed earthenware, painted with brown pigment

Purchased in memory of Georgiana L.

1957-34-1 


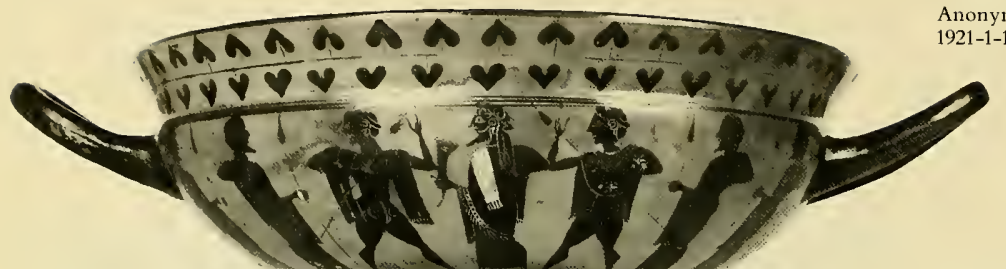
Anonymous gift 1921-1-1

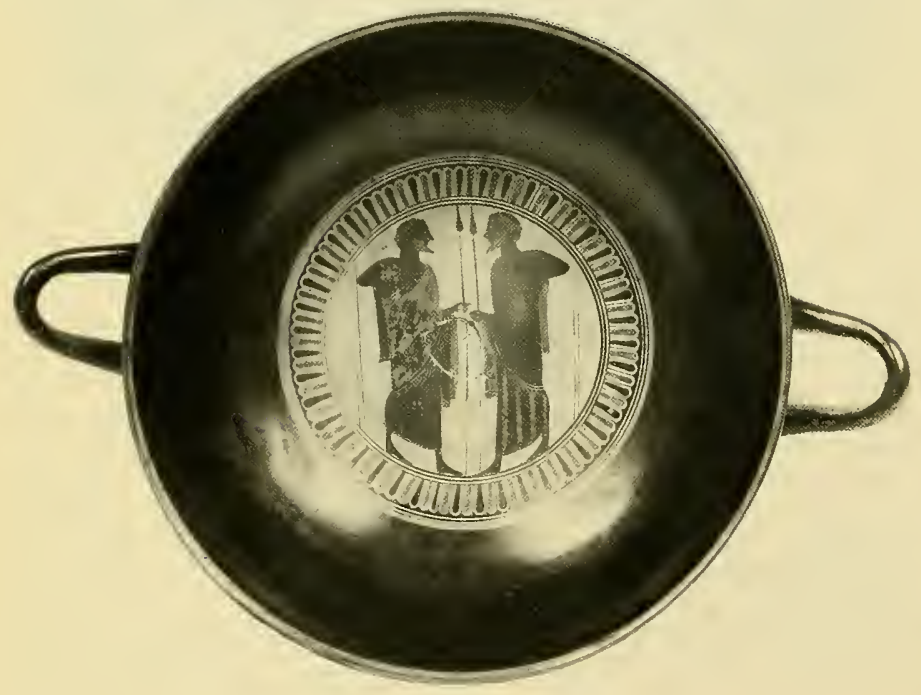

lines to add further detail. Although the figures appear somewhat flat and stylized, their individuality and animation indicate that the painter was one of unusual talent. The figures are arranged within a band that encircles the body of the vessel and at the same time creates an area of implied spatial depth in which the figures reside. The solidity and clarity of the basic form is emphasized by two bands of decoration; stylized leaves arranged in a half-step repeat clearly delineate the everted lip of the vessel, while a geometric band and radiating pattern visually signal the curved underside of the vessel and its logical juncture with the spreading foot.

The style of the painting on this kylix, at once disciplined and expressive, is clearly related to that on a group of similar pots that probably all issued from the same studio or workshop. It is on this basis that the Cooper-Hewitt piece, which is unsigned (actual signed works by other artists of the period do exist), is attributed to the so-called Heidelberg painter. An important indication of the quality of Greek pottery decoration is the clear understand- 
ing that it displays of relationships between form, function, and decoration. Within the boundaries of function and the limitations of form, the potter has achieved a new synthesis of coherent visual organization in which the decoration emphasizes the form. This unity of form and decoration, shape and surface, has continued to characterize the production of pottery through the centuries and stands as the foundation of design.

Egypt's pottery tradition was flourishing as early as 4000 B.C. A large jar in the Cooper-Hewitt collection (Figure 3) reveals the technical skill of Egyptian potters in the production of useful but elegantly painted forms. This jar, which is dated to the late fourth or early third century B.C., was recovered from an Alexandrian tomb in 1884.

The robust shape of the vessel is typical of Egyptian utilitarian pottery; simple decoration includes horizontal bands and foliate motifs over a lighter ground color. The pale ground was made possible by adding a layer of slip-a creamy mixture of fine clay and water - which provided a smooth, pale "canvas" for painted de-

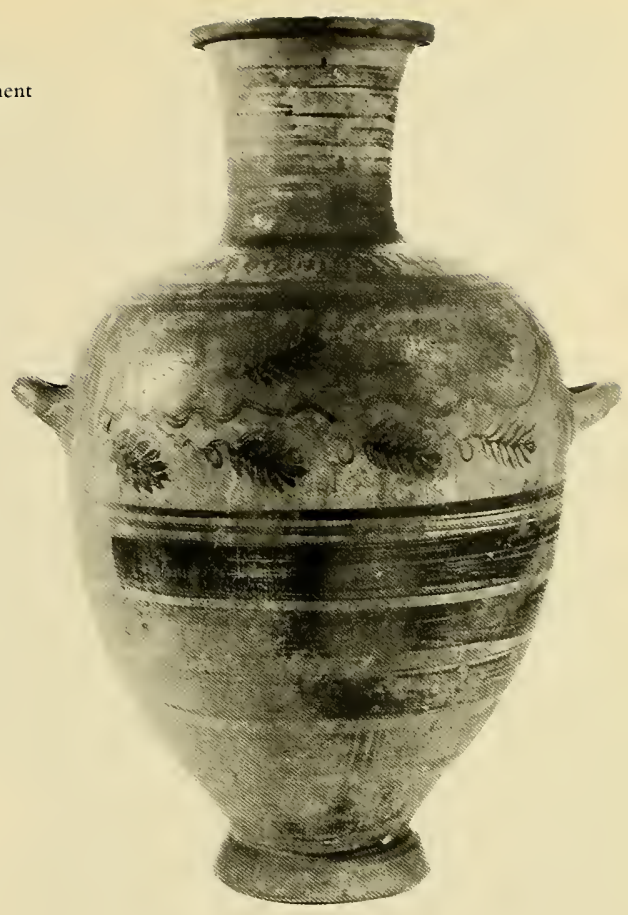

coration. Egyptian pottery of this late period, well after the golden years of Pharaonic rule, is generally less impressive than Greek or Roman pottery made at the same time. However, the survival of the craft over centuries of social and political change does reiterate the importance of the potter to society. Along with furniture makers, glassblowers, and textile weavers, potters have produced work that has been in continuous demand. However, the advent of machine produced goods for everyday use made the workshop appear redundant and inefficient. As shall be seen, such developments in the craft radically altered the role of the potter within society, and that change of status directed potters toward new fields of design experimentation, particularly in the nineteenth and twentieth centuries. 
The impressive history of pottery in the Far East can only be suggested in this survey, since the pottery traditions of China, Japan, and Korea are a field of study within themselves. The history of ceramics in the East has been distinguished by the genius of Chinese potters, who, as early as the archaic period, brought the craft within the sphere of the fine arts. Chinese pottery, even that from the Neolithic period, is endowed with a sophisticated and mystical quality of form and decoration far in advance of the Western world. The spirit of aesthetic intelligence, which matured early in China, produced an environment in which the potter's art could be nurtured. Early in the history of the craft, Chinese potters had gained a mastery over materials and techniques that freed them to create masterpieces rarely equaled by other cultures. It is also to China that one looks to see the first development of porcelain, the most highly refined, delicate, and demanding of ceramic materials. Although porcelain held pride of place among Chinese ceramics, pottery continued to be produced that reflected the ancient traditions of form and tech-

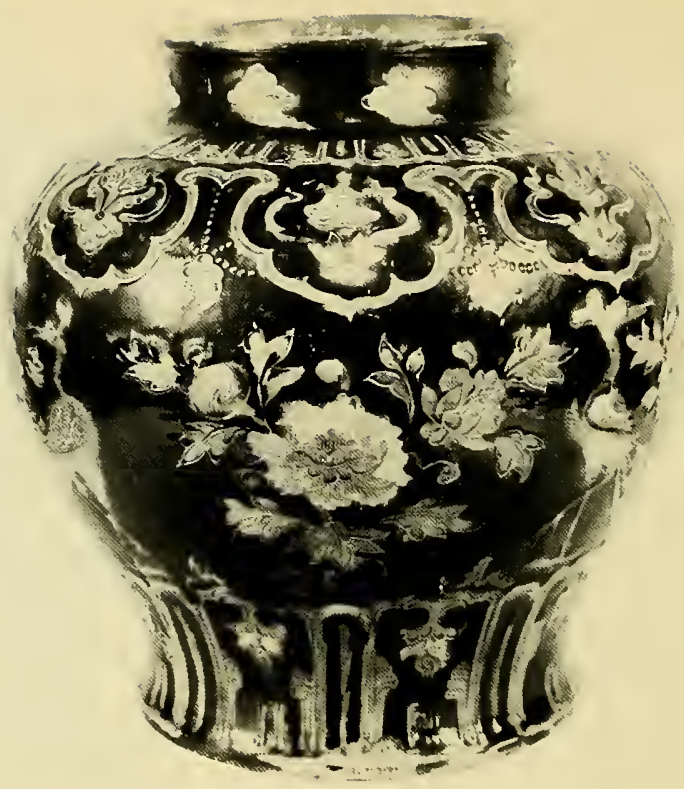

nique but also acknowledged the styles of contemporary porcelain. Certain characteristics of Chinese pottery are suggested by a piece selected from the Cooper-Hewitt collection, a Fa-hua jar dated to the Ming dynasty (1368-1644) (Figure 4). The CooperHewitt jar is decorated with relief and incised motifs drawn from the world of nature, including flowers and birds. The interest of Chinese artists in designs based on the natural world is paralleled by a related sensitivity to pattern, as seen in the scrolled panels that encircle the vase. The decorative motifs are highlighted in a brillant range of yellow, magenta, and turquoise. The decoration is delineated on the surface of the base by fine ridges of clay that separate the color fields, and a visual parallel is thus established between pottery design and work in cloisonné enamel, for which Chinese metalworkers were so justly famous. The refined forms and subtle glazes of Chinese porcelain stand in contrast to this more opulent and showy style of pottery. Both styles reflect the skill of the potter and his ability to organize form and decoration within an aesthetic of supreme sophistication. 
The skills of the Middle and Near Eastern potters have also played an important and influential role in the development of the potter's craft to a fine art. These traditions also indicate the perennial change within the framework of continuity that makes pottery so important in the history of design. An example of Egyptian pottery has already been illustrated, and it was from the Egyptian tradition that another developed. With the collapse of the Fatimids in Egypt, many potters moved to areas where their services could be utilized. Some of them are known to have moved as far as Mesopotamia and present-day Iran. Others can be traced stylistically to Asia Minor. It was in Persia, under the Seljuk dynasty, that many superior examples of the potter's art were produced. The Cooper-Hewitt collection contains a typical Seljuk flower vase (Figure 5) with a central pierced neck and four additional spouts attached to the body. The vase is covered in a rich turquoise blue glaze applied thickly to the surface. The pierced decoration at the neck is covered almost entirely by the melted vitreous glaze, and the end result resembles a still liquid surface.

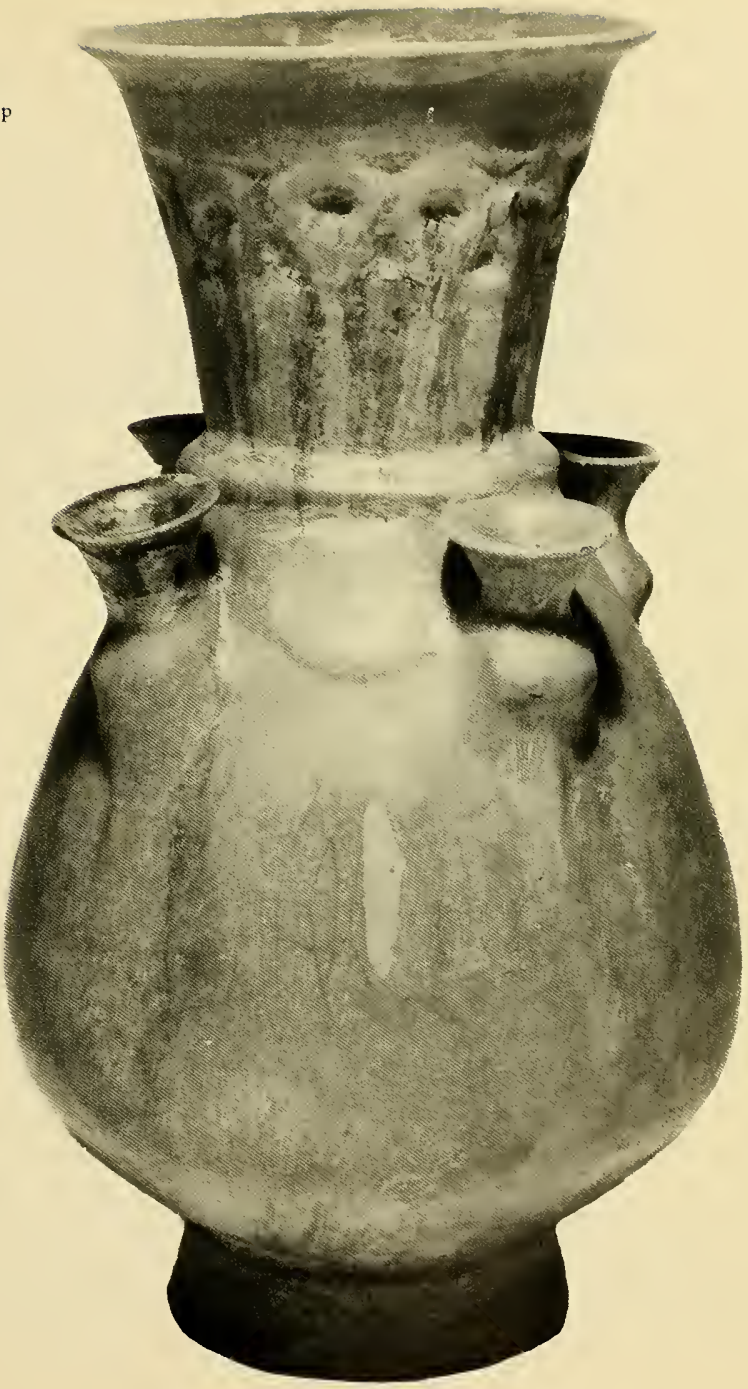




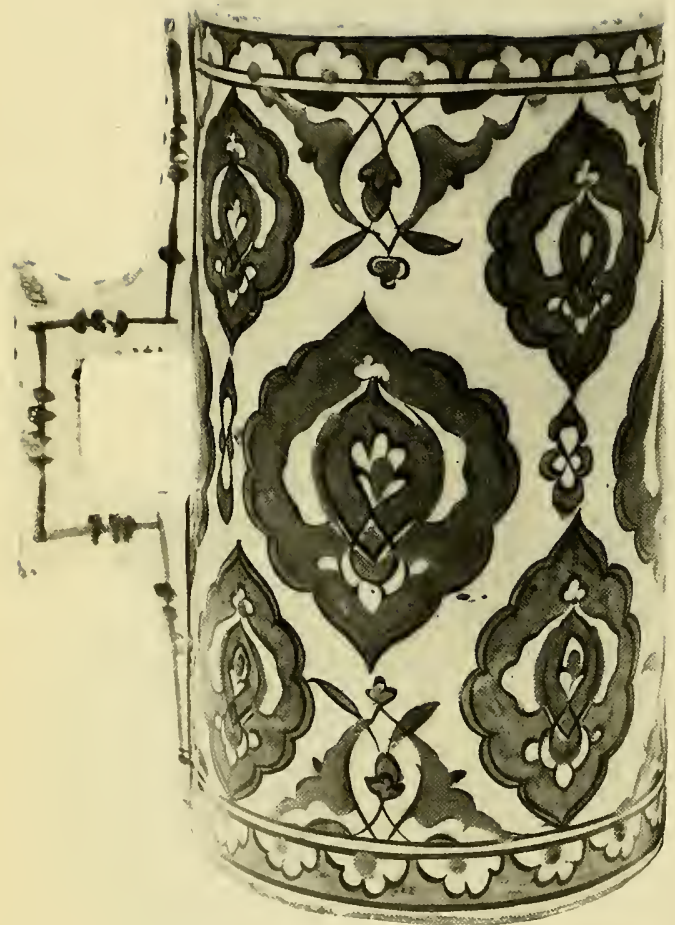

6.

Turkey, Iznik

Handled Vessel, late 16th century

Glazed earthenware

Gift of R. Thornton Wilson

1962-183-1
One of the most important contributions to the history of pottery was the manufacture in the Seljuk area of glazed earthenware for architectural purposes. Many Persian potters fabricated architectural tiles for indoor and outdoor use, and their work had a great influence on the tile traditions of the West. Persian potters also excelled in the production of lustre wares, in which the glazed surface of the pottery was coated with a metallic oxide (frequently copper) and fired once again to produce a lustrous reflective surface of unusual quality. Such wares combined the best of the ceramic tradition with an effect previously achieved only by metalworkers. These popular wares were influential sources of design in the West, particularly in Moorish Spain and Italy.

Another important center that contributed to the design traditions of pottery in the East was the prolific pottery industry in Isnik, located in Western Anatolia. In the Isnik workshops color was always of major importance, and the wares produced during the various periods of Isnik acrivity attest to an appreciation of clear and radiant polychrome. Isnik pottery is 
generally classified stylistically into coherent categories according to painting styles and the colors employed; it was during the second half of the sixteenth century that a distinctive and brilliant red appeared in painted decoration on pottery. A handled vessel (Figure 6) from the Cooper-Hewitt collection illustrates the richly decorated and colorful surfaces of Isnik wares. The body of the vessel is made of a pale clay; the whiteness of the surface was achieved by applying a glaze. This oxide-based glaze, against which the colored decoration stands out in brilliant contrast, was an approximation of the pure white wares of China. As will be seen in later European pottery, a similar desire to imitate porcelain was highly influential in the development of tin-glazed pottery in the West.

The decoration on this vessel is typical of Isnik design during the late sixteenth century; the isolated motifs of striking color, based on natural foliate forms, have been stylized into shaped, pointed ovals arranged in a repeat pattern. The handle on the vessel, in its flatness and angularity, suggests that the prototype for the shape may be found in metalwork. Although the relationship of this form to metalwork may be peripheral, it does underline the close relationship that frequently has existed between potters and metalsmiths throughout the history of the decorative arts. Each artist is, of course, influenced by the general cultural environment in which the work is accomplished, and since potters and metalworkers were often involved in making vessels and objects that performed similar functions, it is not surprising that this relationship exists.

Following the collapse of the Roman Empire, pottery continued to be made in many European centers, although there were few instances of brilliance to mark the progress of styles. Concurrent developments in the Far, Middle, and Near Eastern areas continued to set the standards of excellence throughout the civilized world. Reports of the ceramic treasures of the Orient, such as that provided by the traveler Marco Polo, filtered into medieval Europe. Europeans were accustomed to rather plain and unsophisticated utilitarian wares, and early imports of Chinese porcelains inflamed the imaginations of Western collectors and potters. There were tentative attempts among European potters to simulate the elegance of exotic imported wares, but it was not until the Renaissance that a new tradition of European pottery appeared. In European potteries active during the fifteenth and sixteenth centuries, many techniques from earlier Roman periods reappeared, including the use of a clear lead glaze that provided a shiny and impervious surface. Lead glazes were composed of a basic mixture of sand, salt, and an alkali derived from potash, fused with a lead oxide or galena. This formula could produce a colorless but shiny glaze that revealed the color of the clay beneath it, or it could be colored by the addition of minerals; copper, for instance, rendered the glaze either clear green or brown, without causing the glaze to become opaque. Lead glazes were used throughout Europe during the Renaissance, but the technique was brought to a new level of proficiency in the workshop of Bernard Palissy, a potter active at Saintes, France. Palissy's work gained much admiration from the aristocracy. By 1566 he had moved to Paris at the request of Catherine de Medici, who was to become his most 


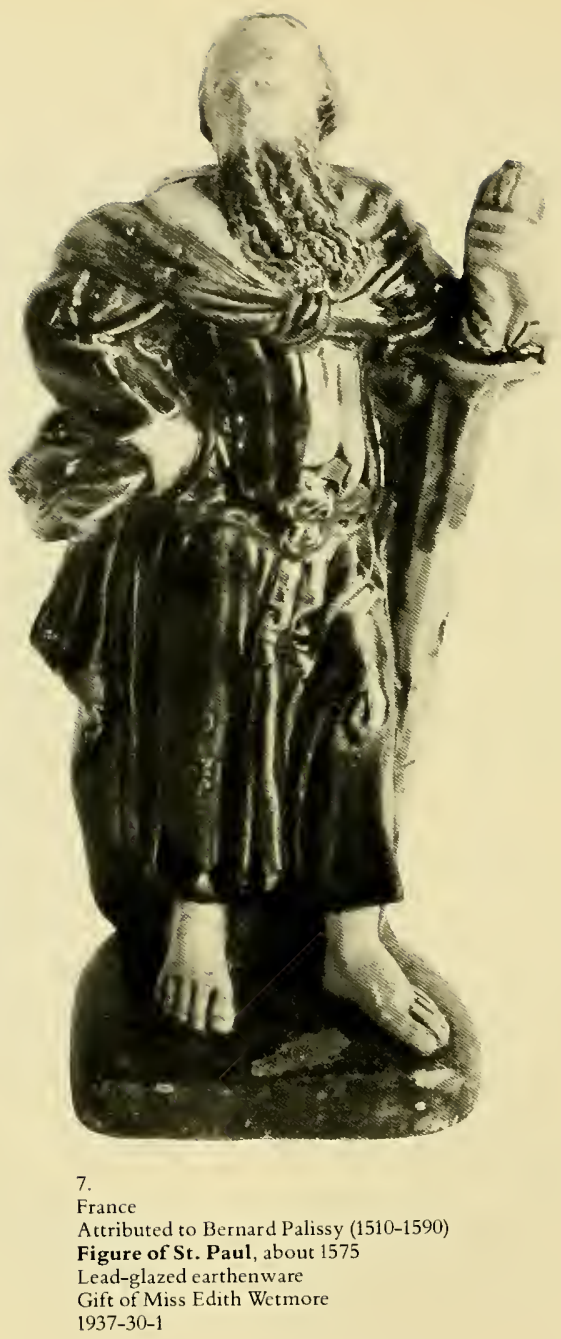

distinguished patron. His reputation was not only based upon his mastery of the lead glaze but also upon his fertile imagination. He made clay the vehicle for strong and vital sculptural statements. Certain figures produced at the Palissy workshop are known to have been derived from originals by sculptors such as Jean Goujon, but models have also been traced to contemporary metalwork. Typical of Palissy-type work is a figure of St. Paul, now in the Cooper-Hewitt collection (Figure 7). The diminutive figure of the saint is monumental in conception; dressed in a full and complicated drapery that reveals the structure of the figure beneath, the saint wears a dignified, yet animated, expression. The clear and sparkling lead glaze includes a brilliant blue on the robe, a brown cape, and a green plinth, with a natural clay flesh tone for the hands and face. Palissy's work, particularly his immutable sense of sculptural form, clearly strikes an early parallel to more recent developments in the field of ceramic arts in which the line of distinction between art and craft has-become uncertain. 


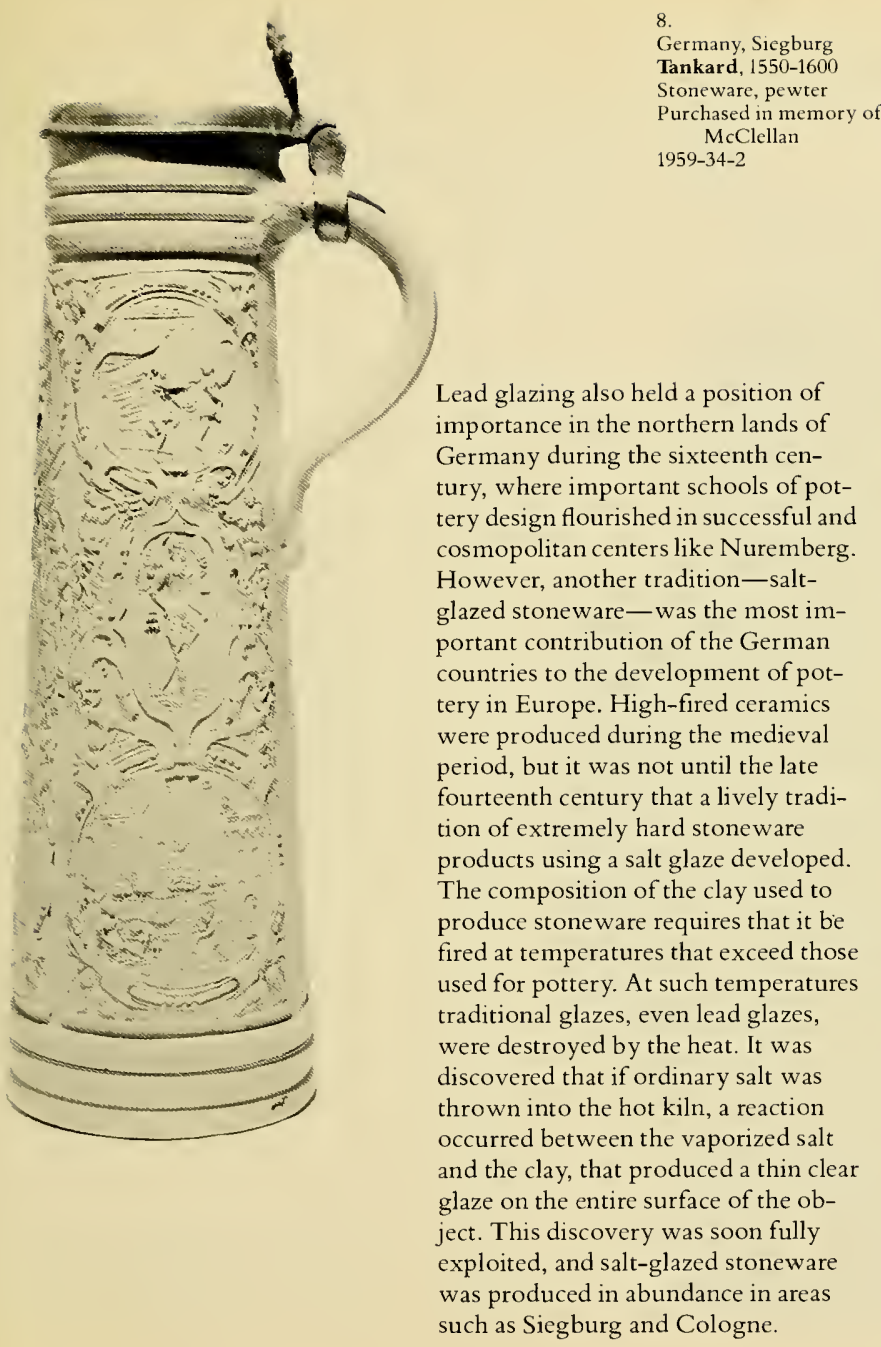

Typical of late sixteenth-century Siegburg stoneware is a tall tankard in the Cooper-Hewitt collection (Figure 8). The glaze on Siegburg wares allowed the near-white stoneware body to show, and decoration frequently consisted of molded designs. The iconography of this Siegburg jug illustrates both the sacred and the secular aspects of the Renaissance in the North. The body of the piece is covered with interconnected strapwork, scrolls, foliage, and cherubs, clearly inspired by sixteenth-century pattern books. Roundels and ovals enclosed by the strapwork and grotesques are filled with narrative pictorial scenes. Near the handle is a roundel depicting the story of Joseph with Potiphar's wife. Below that is a figure of a knight, and at the lower part of the body is a view of a sixteenth-century town not unlike Siegburg itself, peopled with characters from the story of David and Bathsheba. The techniques of molding can be seen in this example; each pictorial and ornamental panel is duplicated three times around the body of the tankard, and the juncture between molded sections is clearly visible. 


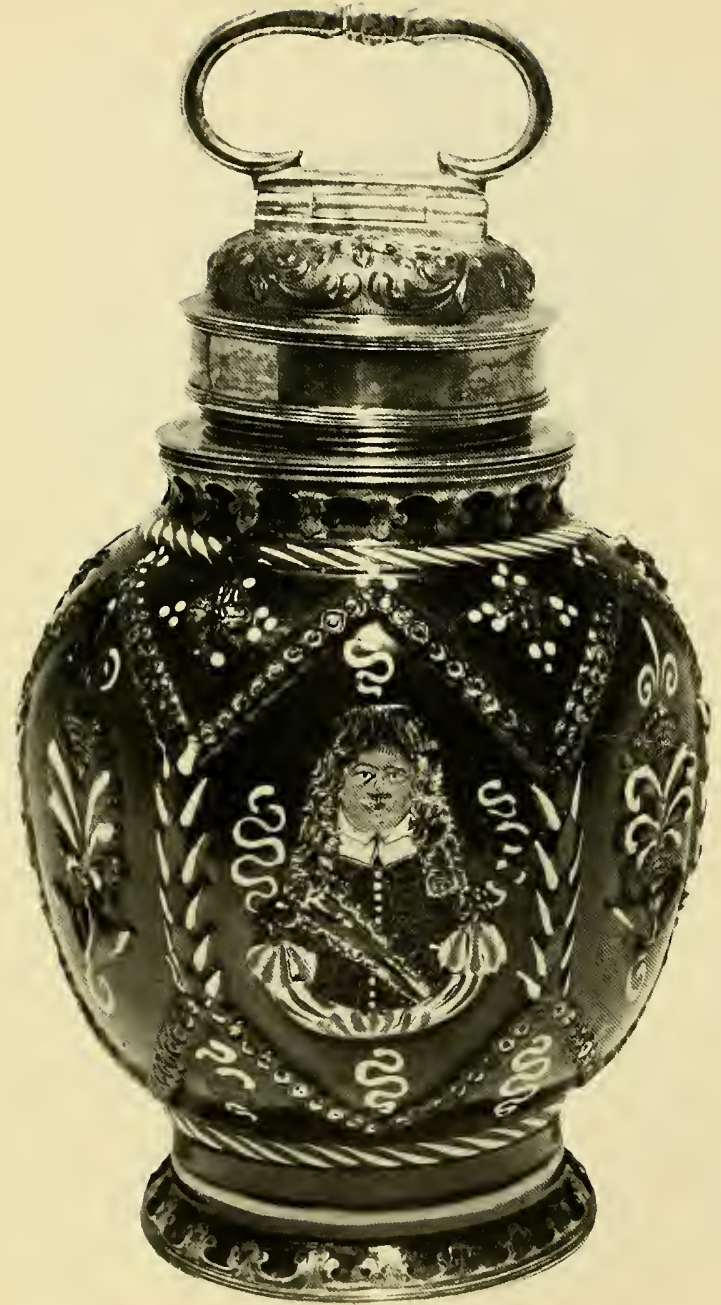

9.

Germany, Saxony

Jar, about 1675

Stoneware, silver

Gift of Milton J. Blume

1957-174-1

The stoneware traditions of Germany continued, with changes over time in ornamentation, color, and molded decoration that kept pace with the general artistic climate. Even as late as the end of the seventeenth century, molded stoneware vessels clearly descended from the Siegburg wares were still being produced (Figure 9). In this late example, the molded decoration consists of bust-length portraits alternating with stylized floral devices. Each relief is framed by stamped lozenge-shaped borders. A carry-over from the earlier tradition is the combination of stoneware with metal mounts at the foot and neck; in this instance, the mounts bear the mark of a Munich silversmith, Franz Oxner (died 1688). The dark brown glaze of the jar is counterbalanced by brilliant enamel painting in shades of red, blue, white, and yellow, and the overall effect is more exuberant and secular than the earlier Siegburg example illustrated.

Among the most important types of pottery made in Europe from the Renaissance onward was tin-glazed earthenware; the creamy white surface 
of this pottery was produced by introducing tin ash into a basic lead glaze. The result-a nearly pure white opaque glaze - could be used to obscure the native color of the humble clay beneath the glaze, thus providing potters with a sparkling canvas that received painted decoration readily. Tin-glazed earthenware is commonly known by a variety of names related to the geographic regions in which it was produced: faience in French-speaking areas; maiolica in Italy; and delftware in England and Holland. Each country developed particular styles for ornamenting this surface, and several alternatives were available to the painters responsible for the decoration of the pieces. Color and pattern could be painted on the unfired tin-oxide glaze with metallic pigments able to withstand the high heat of the kiln. "Underglaze" colors, those pigments fired with the tin glaze, became irrevocably conjoined with the glaze surface.

Cobalt was used to produce a spectacular blue, manganese for a rich brown purple, copper produced a green, and iron an intense red. Yellow was achieved by using antimony.
A second technique of color application could be utilized after the object had been fired to a pristine whiteness. Enamels-pigments in a fusible glass powder - could be painted on the smooth glazed surface; a second firing at a reduced temperature "fixed" the enamels to the surface of the glaze. These "overglaze" colors did not become absorbed by the glaze in the same manner as underglaze colors.

The knowledge of tin-glazing arrived in Europe by a long and complicated route that began in the Near East. It was due to Islamic potters that the technique eventually arrived in Spain, from whence it later travelled to potteries all over continental Europe and England. Italian tin-glazed wares were being produced at least as early as the twelfth century, but the major flowering of maiolica occurred in the fourteenth and fifteenth centuries. Although there were many centers in Italy that produced fine maiolicaDeruta, Faenza, and Cafaggiolo, for example-one of the most active potteries, that of Gubbio, is represented in the Museum collection by a circular plate painted with a figure of Orpheus (Figure 10). The painterly quality of this dish is typical of Italian Renaissance pottery. A classical subject is depicted in contemporary guise; Orpheus is dressed in sixteenth-century costume and plays a viola rather than a more purely antique lyre. The scene is painted in the brilliant underglaze colors available at the time and reveals a dependence upon canvas painting of the period. The art of Italian maiolica is often that of the painter rather than the potter, since the form of the object is clearly secondary to its narrative or pictorial content. In this instance, the painter has even signed his composition "M.G." for Maestro Giorgio Andreoli, and dated the work 1536. The legibility of the narrative indicates a function of pottery quite distinct from the more purely "patterned" wares already discussed. The multitude of aesthetic ends that pottery has served, including that of a narrative document capable of expressing literary, philosophical, and poetic concepts, has given the craft a continuing vitality into our own time. 


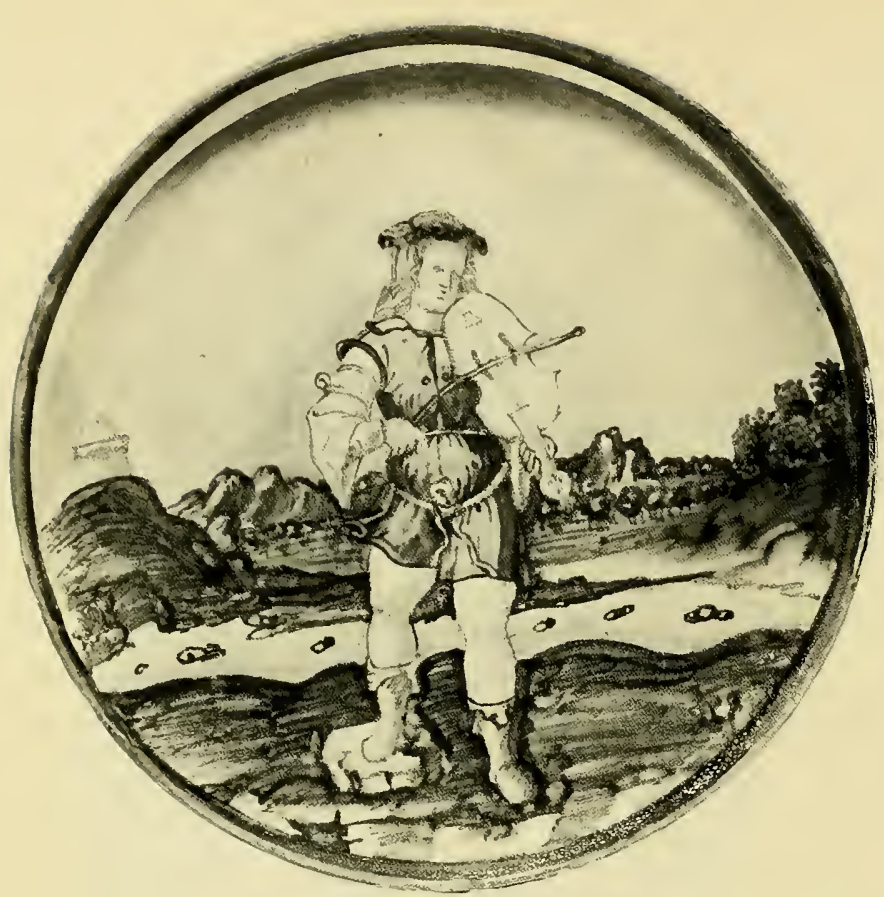

Tin-glazed wares from France are well represented in the Cooper-Hewitt collection. A footed urn (Figure 11) made in Moustiers about 1735 strikes a balance between the pattern tradition and that of factual information. The underglaze cobalt blue decoration of this piece consists of elaborate and finely painted arabesque and lambrequin borders related in spirit to the work of the prolific designer Jean Berain (1637-1711). Intended for use as a display piece, the urn contains a per- sonalized reference to its owner in the form of an elaborate feather-

mantled-and-bannered coat of arms, complete with smoking cannons and other trophies of war. The shape of the urn exemplifies baroque taste, with a robust circular form, molded gadrooning, and mask handles. The factory at Moustiers was responsbile for the production of impressive display faience, such as this example, undoubtedly a special order from an aristocratic client. However, many
10.

Italy, Gubbio, signed "M.G."

Plate, 1536

Earthenware, tin-glazed, polychrome underglaze painting

Gift of R. Thornton Wilson

1962-80-1 simpler forms were also produced for more-or-less everday use, such as bowls and covers, mustard pots, and soup plates. As noted in earlier potters' wares, the relationship in design and forms between potters' wares and those of metalworkers remained a close one; an urn such as this may have been as logically fabricated in silver, and similar examples can be documented. To finance costly wars, Louis XIV required the aristocracy to turn in their silver to be melted down 


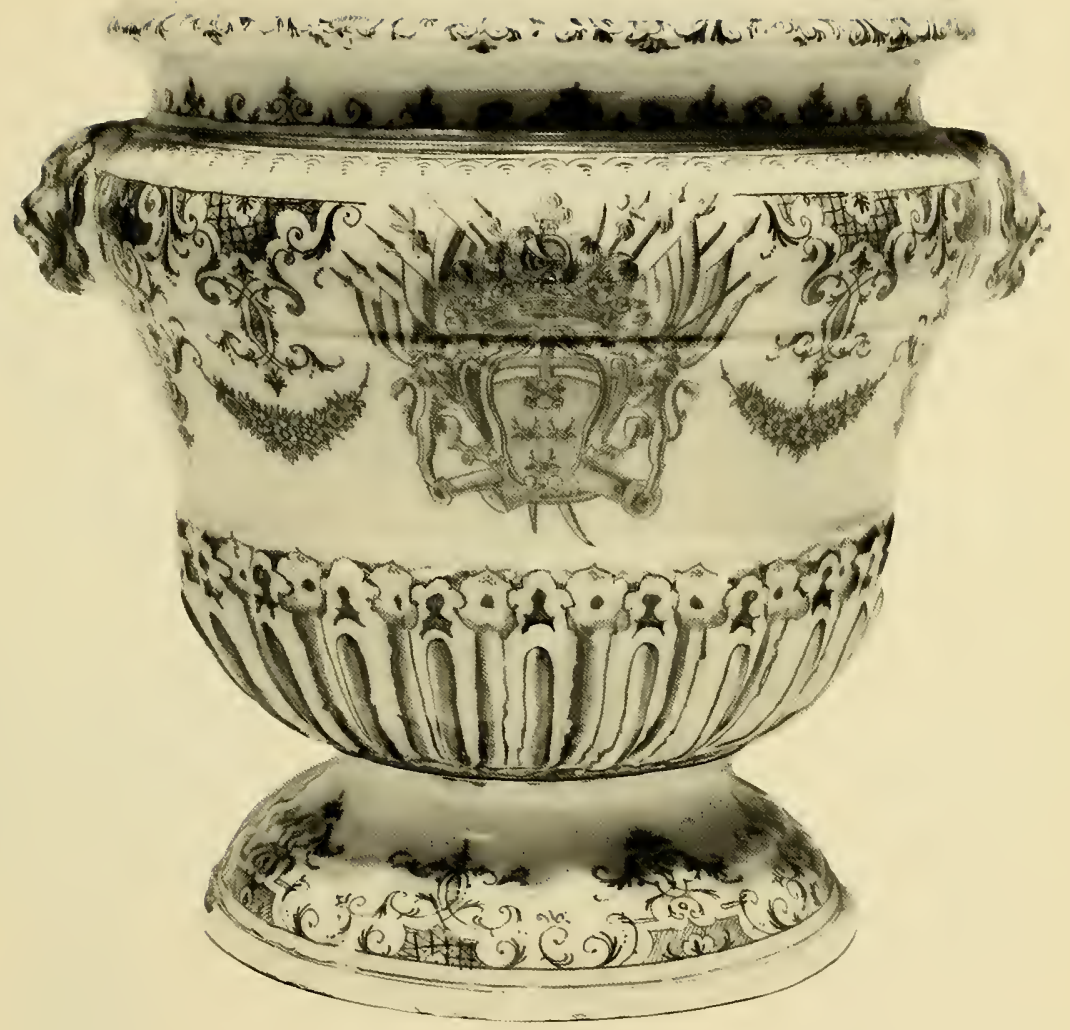

11.

France, Moustiers

Urn, about 1735

Earthenware, tin-glazed, underglaze decoration

Gift of Miss Catherine Oglesby

1959-89-1 
12.

France, probably Nevers

Cap or Wig Stands, late 17 th century

Earthenware, tin-glazed, underglaze decoration

Bequest of Richard Cranch Greenleaf, in memory of his mother, Adeline Emma Greenleaf 1962-60-2, 4

for bullion. Many distinguished families then furnished their tables with the finest of faience (or, later, porcelain), and the craft of the potters in France received added impetus due to this royal action.

Throughout the seventeenth and eighteenth centuries, Europeans continued to be fascinated by the Orient; much Chinese porcelain (frequently of the blue-and-white variety) was imported to major European centers, and the effect on the design vocabulary of potters can be easily illustrated. A pair of hat or wig stands (Figure 12), although made for an expressly European fashion, is decorated with scenes that evoke the world of the East. Painted in underglaze cobalt and manganese, each stand depicts

Chinese figures within an atmospheric landscape that consists of isolated elements such as rocks, trees, and earth.

Chinese-inspired decoration was not always as restrained and poetic as it is on these stands and in some instances was bold, theatrical, and even garish, as in a soup tureen in the Museum collection (Figure 13) which has been

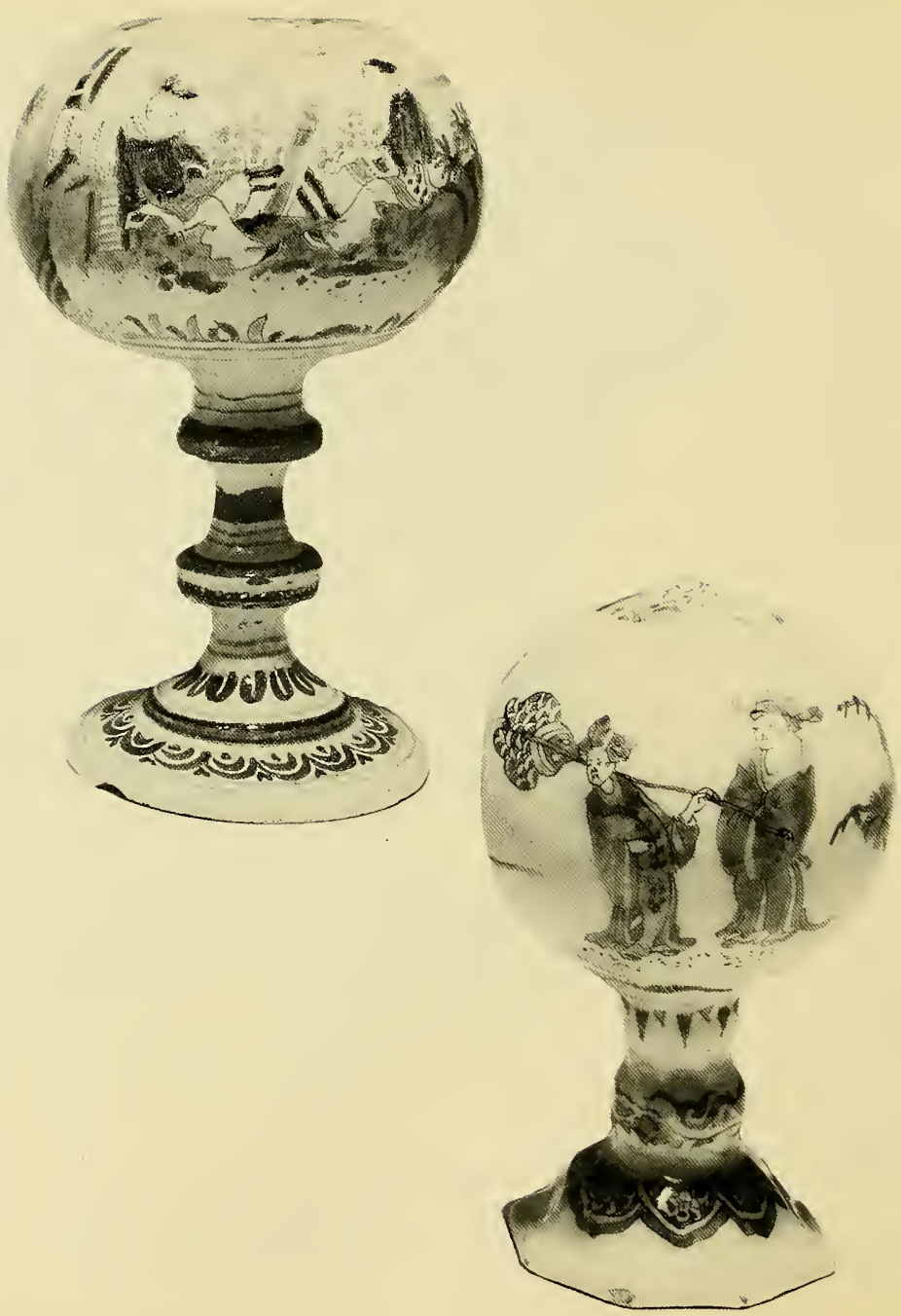




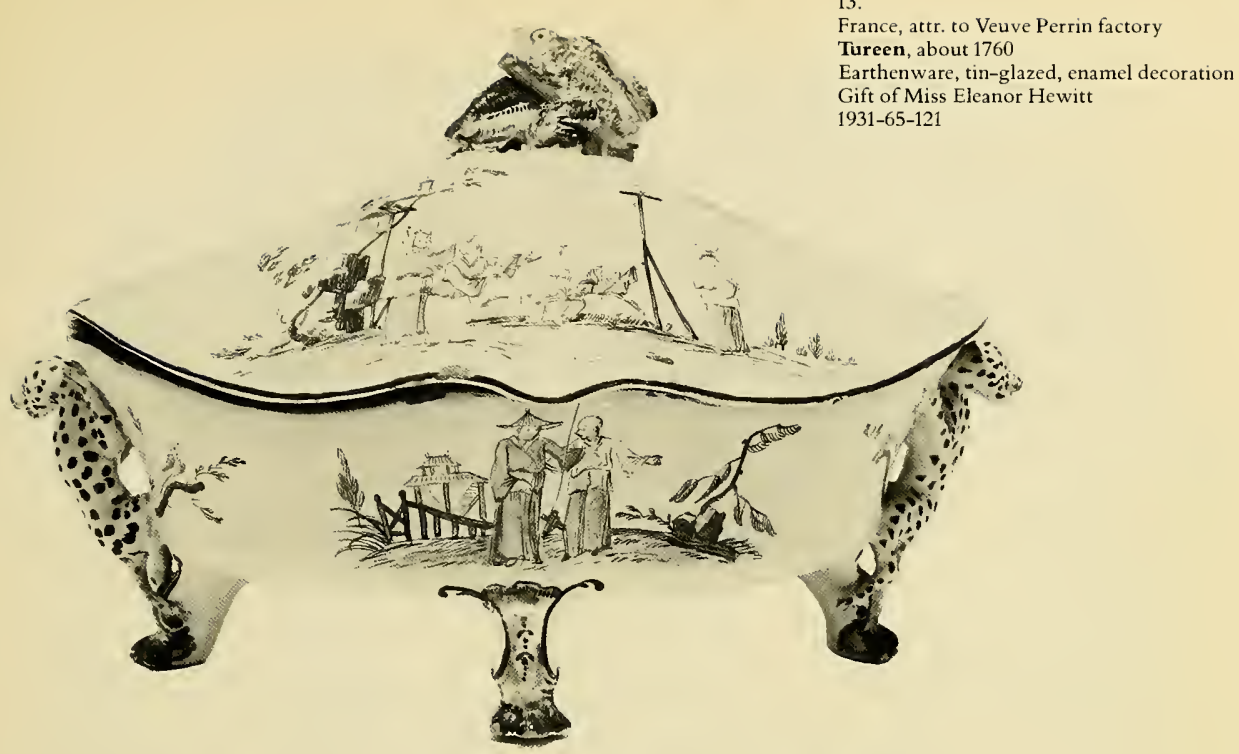

attributed to the factory of Veuve Perrin, known for its brilliantly enameled wares of unusually fine quality. By the middle years of the eighteenth century, porcelain factories had been founded throughout Europe, and pottery concerns were facing stiff competition. In comparison to the refined porcelain of Meissen and Sèvres, pottery was a humble relative, but potters continued to produce a vast array of forms for those who could not afford the more expensive luxury. Factories such as those at Marseilles, Niderviller, Strasbourg, and Sceaux maintained an active staff of designers, modelers, glazers, and painters during the second half of the century, but they were eclipsed by the growing availability of porcelain and the very real challenge offered by the successful potters of England.

The next important highwater mark in the history of European pottery occurred in the small factories of Staffordshire in England, and the name that has become synonymous with English pottery of the late eighteenth century is that of the brilliant innovator Josiah Wedgwood (17301795).
Wedgwood, who was from a family of Staffordshire potters, entered into partnership with the potter Thomas Whieldon in 1754. Many of Wedgwood's critical strides in pottery production were the result of his zealous research into various glazes and clay mixtures. By 1769 he had established an expanded pottery works named Etruria, a reference to the spirit of antiquity that Wedgwood captured in his refined neoclassical wares. Several distinct developments in the means, methods, and materials of pottery making are ascribed to Wedgwood. Among the important pottery bodies 
14.

Josiah Wedgwood (1730-1795), Etruria factory

England

Bowl, tray, and ladle, about 1780

Earthenware ("Queen's Ware"), overglaze decoration

Bequest of Erskine Hewitt

1938-57-428

developed to a point of perfection at the Wedgwood factory was a fine earthenware covered with a creamy white glaze that suited admirably the simple and elegant forms molded at the factory (Figure 14). This creamcolored ware, called Queen's Ware after he had received Queen Charlotte's patronage, is painted with delicate borders of classical husks and garlands, in a warm brown that further emphasizes the creamy body. Standard domestic forms-plates, bowls, and tureens-were massproduced at his factory; the high quality of the wares, the low cost of materials and labor, and the suitability of the designs for a market that had left behind the frivolity of the rococo for a purer form of classicism made the wares an instant success, as well as a rival to porcelain.

In addition to the popular creamcolored wares, Wedgwood introduced a series of highly refined stoneware bodies-jasper ware and basaltes ware-made of colored clays that fired to a rich tone and offered an entirely new range of color possibilities, including a dramatic black basaltes ware, an example of which is in the collection of the Cooper-Hewitt Museum (Figure 15). The Cooper-Hewitt's root pot is fitted with a removable holder in which bulbs or blossoms can be inserted. The classically inspired decoration of putti carrying flower garlands is picked out in a bold terra-cotta 


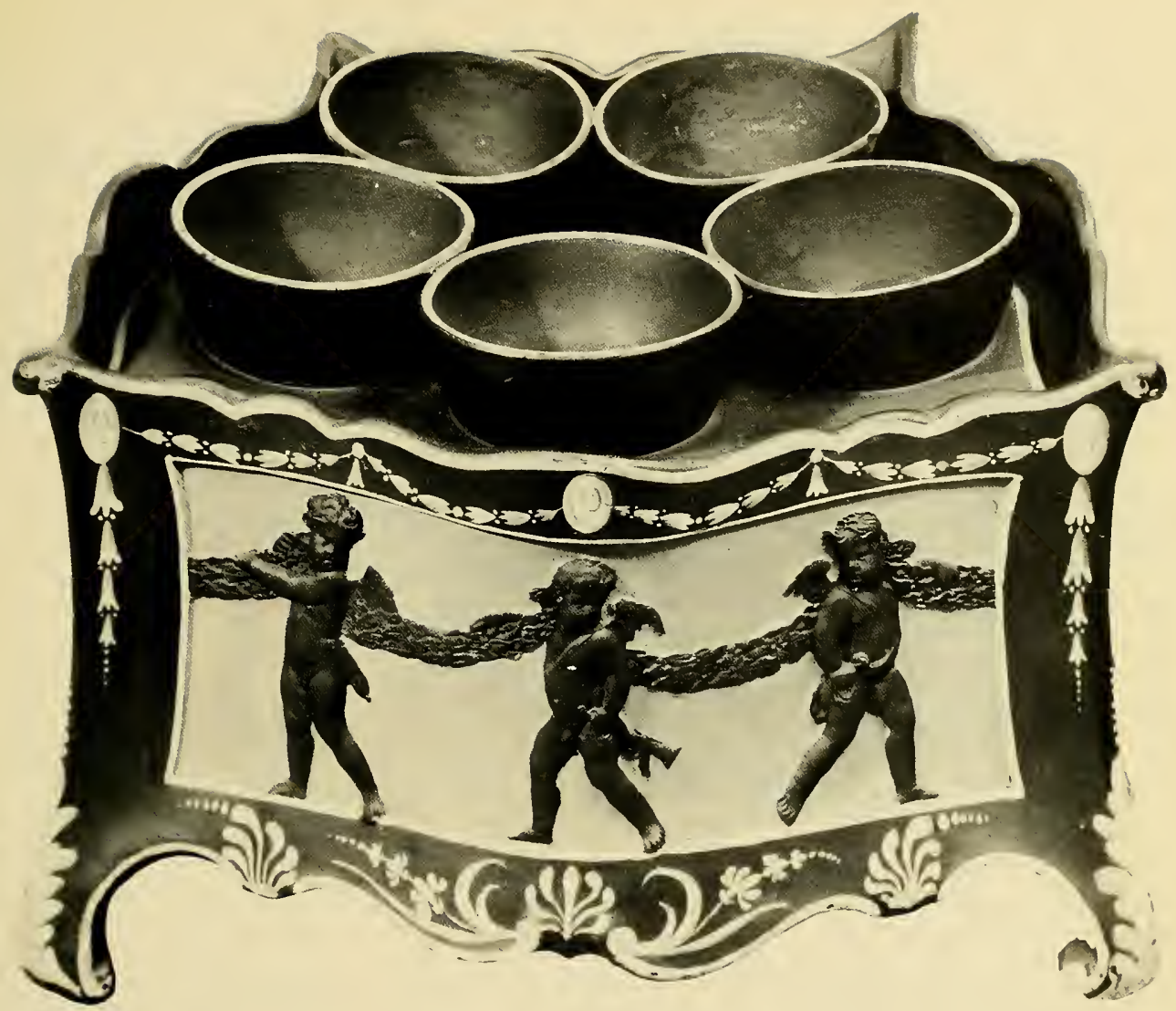

15.

Josiah Wedgwood (1730-1795), Etruria factory

England

Root Pot, 1780-1800

Black basaltes, encaustic painted decoration

Bequest of Erskine Hewitt

1938-57-316 
16.

John Turner (1739-1786)

England, Staffordshire

Teapot, about 1780

Stoneware, enamel decoration

Bequest of Erskine Hewitt 1938-57-317

color, and additional painted details in a striking pink are produced in a process misleadingly called encaustic by Wedgwood himself.

\section{Although Wedgwood is by far the} most familiar of the great artist-potters of the eighteenth century, he was not working alone, and the fine work of his contemporaries and competitors has often been unfairly overshadowed by Wedgwood's fame. One such contemporary, whose work is of the finest quality, was John Turner (died 1786), also of Staffordshire (Figure 16).

Turner's excellence as a designer is well illustrated by this teapot, which cleverly incorporates an unusual sliding cover. The form of this vessel is

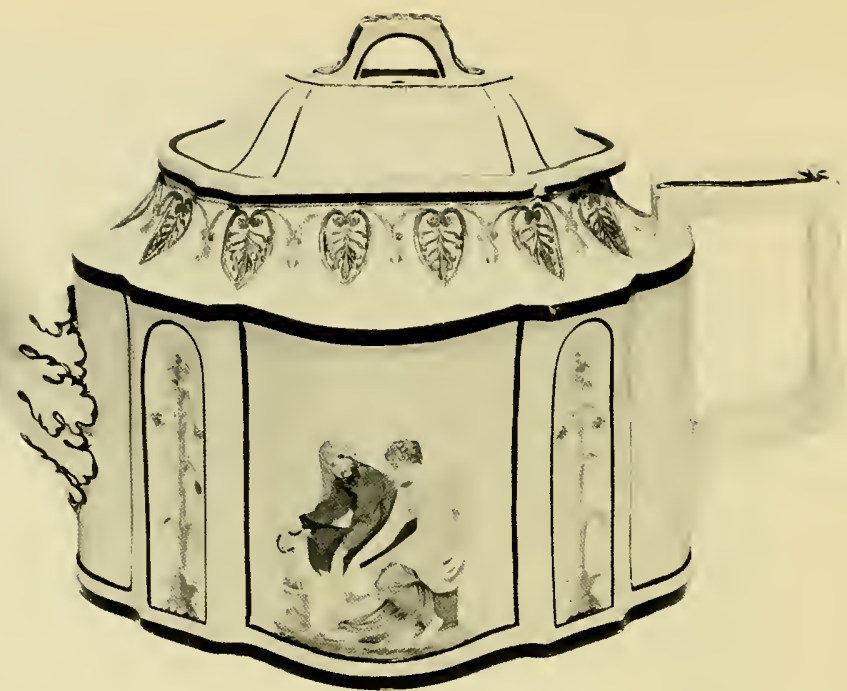

identical to examples in silver made in London at approximately the same time, but the applied decoration in delicate pastel colors and a bold oxblood red, produces an effect not possible in metal.

During the nineteenth century, revived styles were given a new interpretation that reflected popular taste. Many factories produced elaborate pottery that echoed porcelain design of the eighteenth century, but there were also radically new developments, such as a fresh interest in naturalistic and organic sources of design that gave nineteenth-century pottery a special appeal. There were also important innovators active in studios and at factories, designers whose work has remained important and influential in the history of modern pottery.

Mechanization and mass production had made both pottery and porcelain available to a large consumer market; the aesthetic quality of popular design was challenged by enterprising individuals who gave a new vitality to the craft.

One important link between early post-Renaissance pottery in Europe and the modern world should be briefly noted; this is the survival of a folk pottery tradition that continued to exist outside of the mainstream of commercial and studio design. An example of the unselfconscious folk 
tradition is found in a collection of related folk material in the CooperHewitt collection (Figure 17). This platter was made in Switzerland in the late eighteenth or early nineteenth century and is a bold and direct statement of folk aesthetics. A curious parallel, without any direct genealogical connection, may be seen between this platter and the tenth-century B.C. bowl discussed earlier (see Figure 1). Both objects share a spirit of vitality that makes them kindred, although fashioned nearly two thousand years apart. Both potters, while working within a tradition, expressed an energy and individuality in their work that is admired even today.

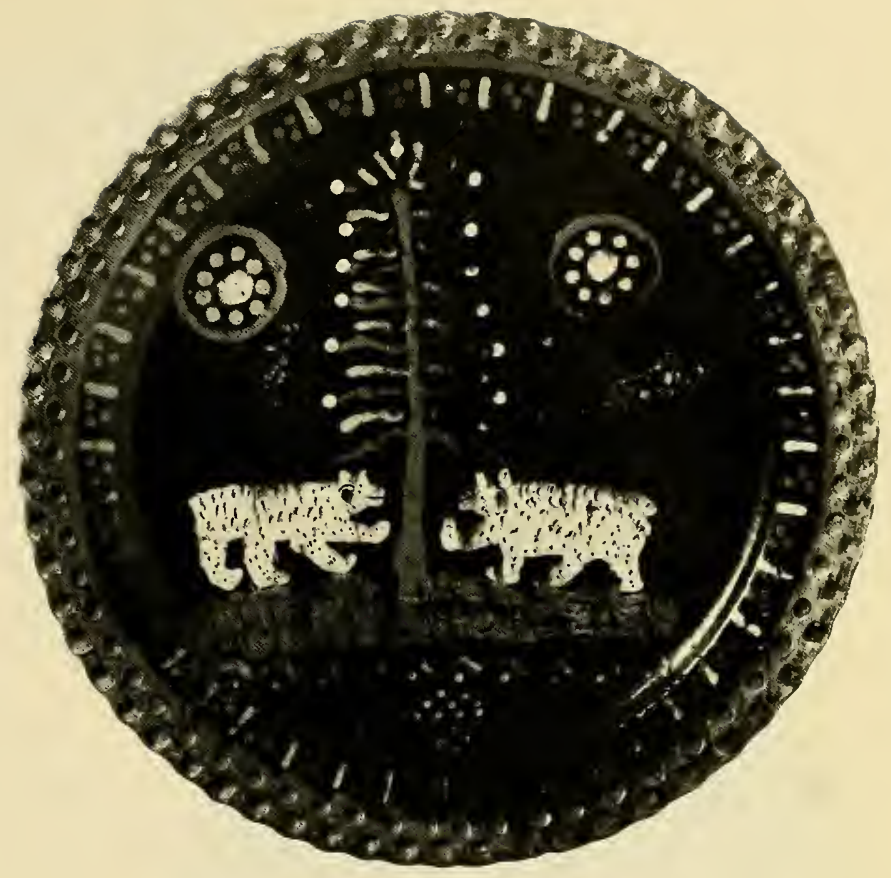

17.

Switzerland

Plate, late 18 th century

Earthenware, slip decoration

From the C. Helme and Alice B. Strater

Collection, gift of C. Helme Strater, Jr.,

John B. Strater and Margaret S. Robinson 1976-1-140 
19.

George Tinworth (1843-1913)

England, executed at Doulton and Co., Lambeth

Jug, about 1869-1872

Stoneware, salt-glazed

Gift of L. Bancel La Farge

1948-33-8

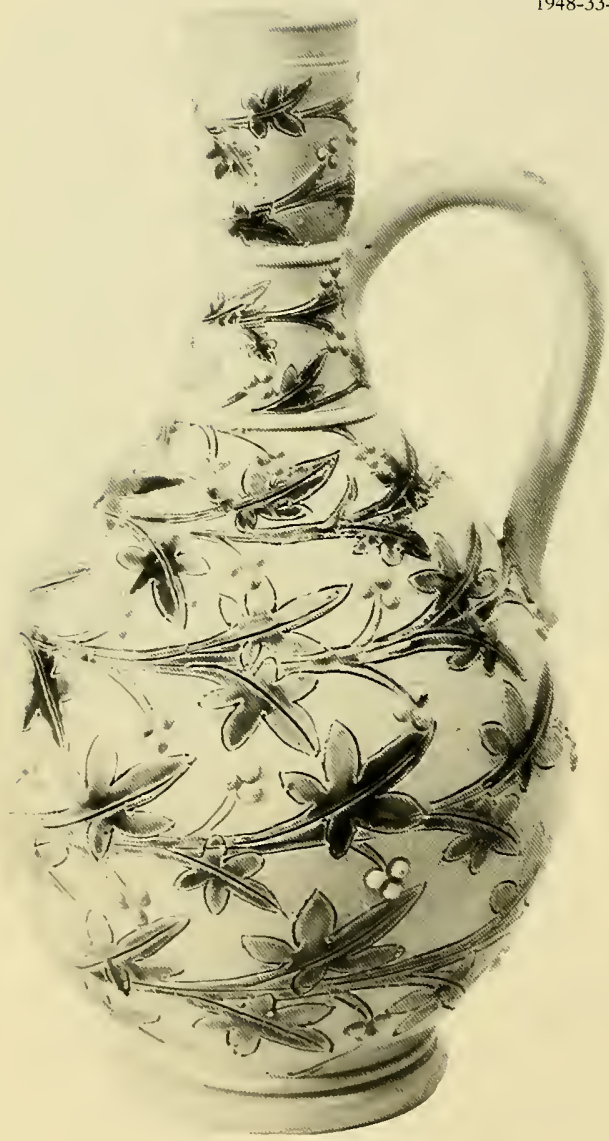

Many potters outside of industrial production appeared during the nineteenth century, and certain leading designers actually worked within the industrial community. Among the more significant of these artists is Théodore Deck (1823-1891). Deck's contributions to the progress of design were many, but among them must be noted his technical interest in rich polychrome glazes. One of these-a superb turquoise, subsequently called bleu de Deck - was particularly favored. Exotic pottery styles, such as the Persian and Japanese, were used by Deck as a springboard for a new stylistic synthesis (Figure 18 Cover). No mere copy or revival, Deck's work recalled the past without being imitative, as he explored the visual potential of color and pattern.

A major nineteenth-century figure within the stoneware tradition was the potter George Tinworth (1843-1913). Tinworth, whose personal mark often appears on his wares, worked at the Doulton Pottery in England. Tinworth's work included freely executed and boldly sculptural compositions; a 
20.

Emile Gallé (1846-1904)

France, Nancy

Dog

Earthenware, enamel decoration, glass

Anonymous gift

1967-48-108

more idyllic and domestic aspect of his work is seen in a handled jug from the Museum collection (Figure 19). Reminiscent of much earlier stoneware in its general form, the design also represents a departure in that the techniques used for making the jug clearly reveal the hand of the artist. The calligraphic scratched decoration of leaves and the mottled blue glaze in contrast to the grey stoneware body clearly indicate the handwork involved in fashioning the piece.

A third major figure of the period is the well-known Emile Galle (18461904), a multi-faceted genius who created glass, furniture and ceramics. One of Gallé's distinctive formshumorous costumed animals-is seen in an example from the CooperHewitt collection (Figure 20). This sculpture is at once realistic and imaginative; the bulging glass eyes lend a stop-motion character to the expressive face, while the painted floral dressing gown worn by the animal provides a multi-level trompe-l'oeil message regarding materials and techniques.
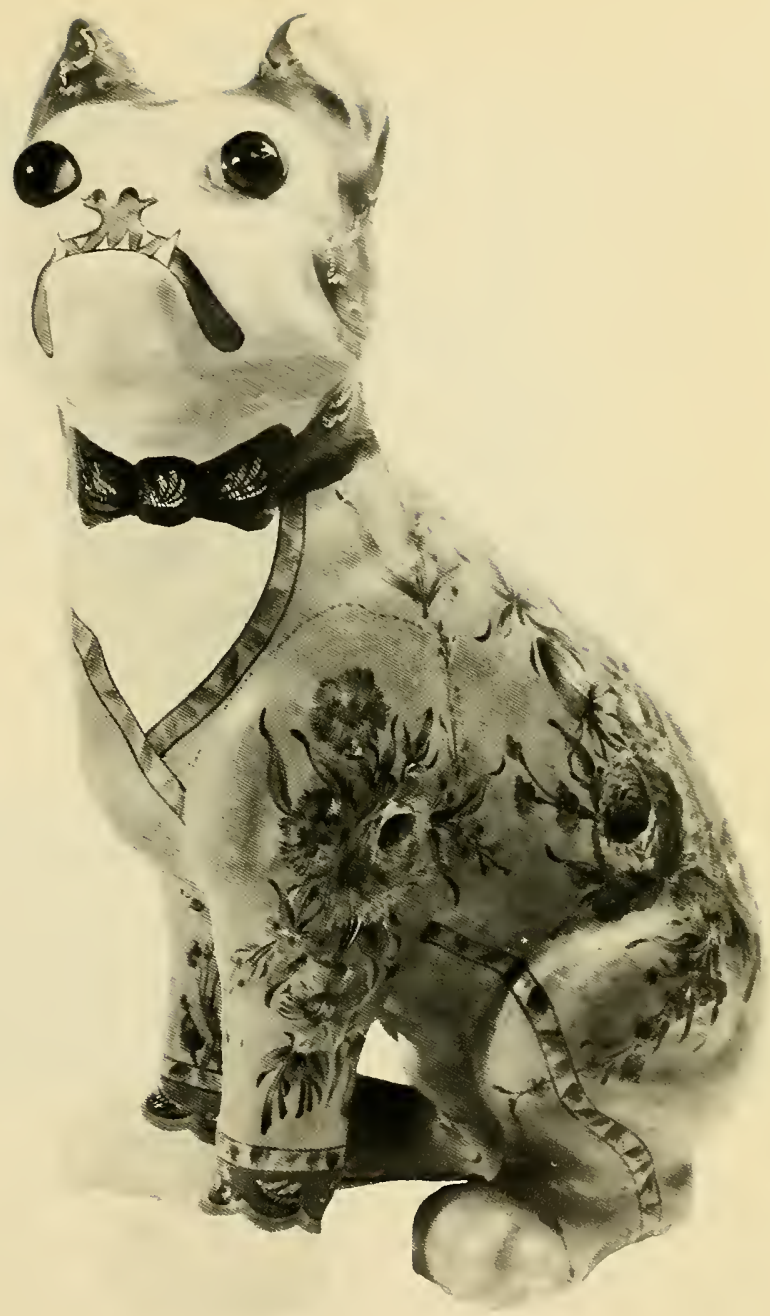


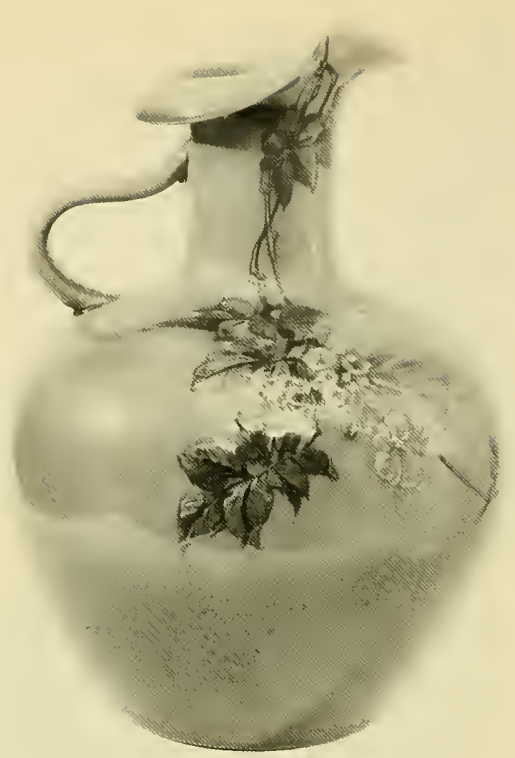

A survey of pottery during the late nineteenth and early twenticth centuries would be incomplete without reference to the American studio of the Rookwood Pottery in Cincinnati, Ohio. Founded in 1880 by Maria Longworth Nichols (Storer), the pottery began as an effort to gain recognition for women who were active pottery painters in the Cincinnati area. This modest effort became the base for a large number of talented pottery artists, who turned a home craft into a fine art. In 1890 the Rookwood Pottery was a warded a gold medal at the Paris Exposition, and throughout the closing years of the nineteenth century and well into the present one, finely executed wares emanated from this pottery (Figure 21).

The rise of the artist-potter during the nineteenth century was paralleled by a growing number of designers who were aligning themselves with industrial production. By the twentieth century, many accomplished designers were working within industry and had contributed significant design statements that took into consideration machine production and the necessities of modern industrialized life. The work of the industrial designers cannot be underestimated, and although their contributions are not within the scope of this catalogue, the Cooper-Hewitt Mnseum continues to collect examples of fine industriallydesigned ceramics.

Notable works from the early decades of this century now in the Museum collection include a ceramic sculpture designed by Willy Wuillemeier, executed by the French firm of Fau and Gaillard (Figure 22). This work, an angular, stylized free-standing relief, was exhibited at the 1924 Salon des Artistes Decorateurs and embodies many of the principles of design in the 1920 s. The subject, St. George and the Dragon, harks back to medieval 


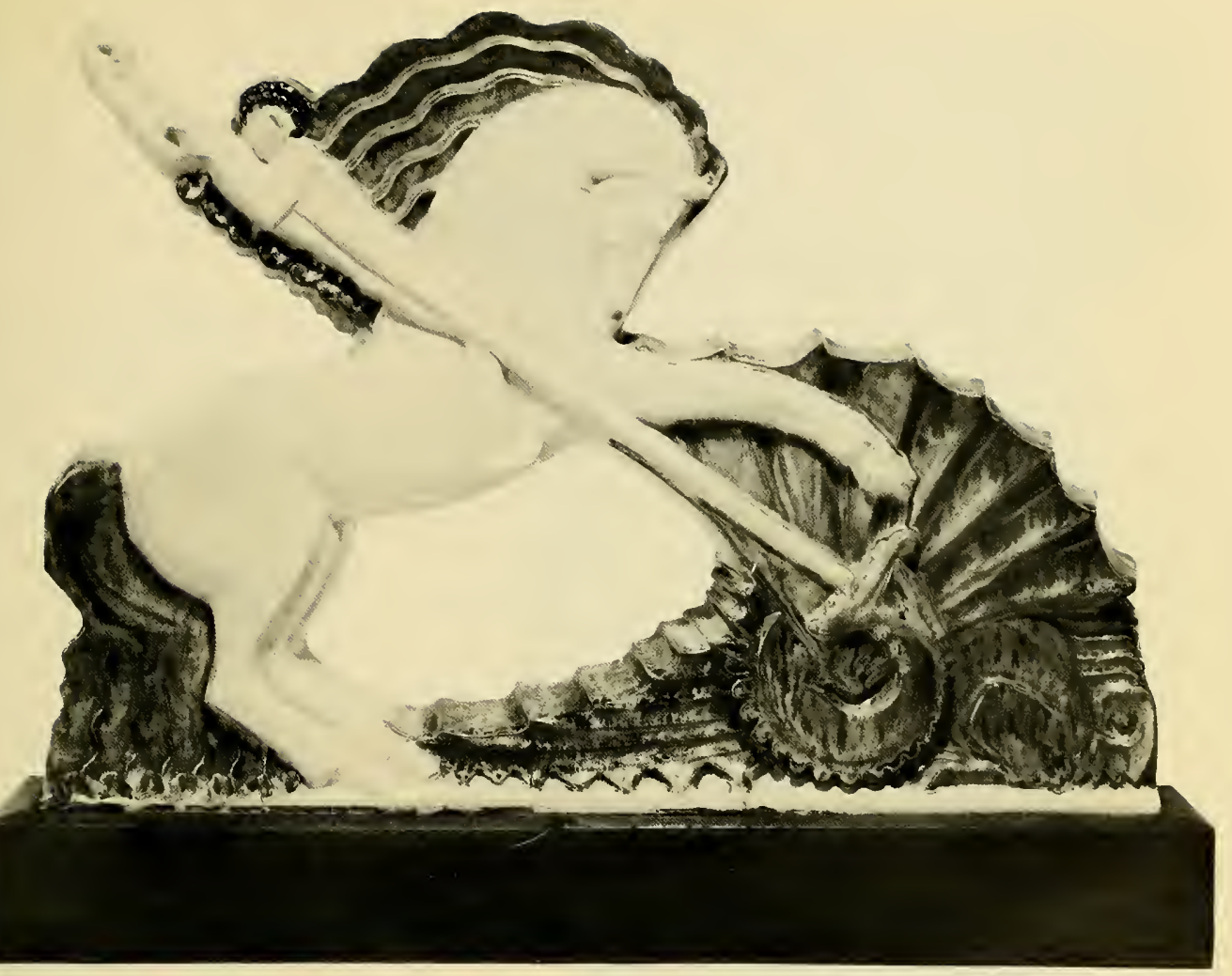

22.

Designed by Willy Wuilleumier

Executed by Fau and Gaillard, Paris

St. George and the Dragon, about 1924

Earthenware

From the collection of the late Stanley Siegel;

the gift of Stanley Siegel

$1975-32-4$ 


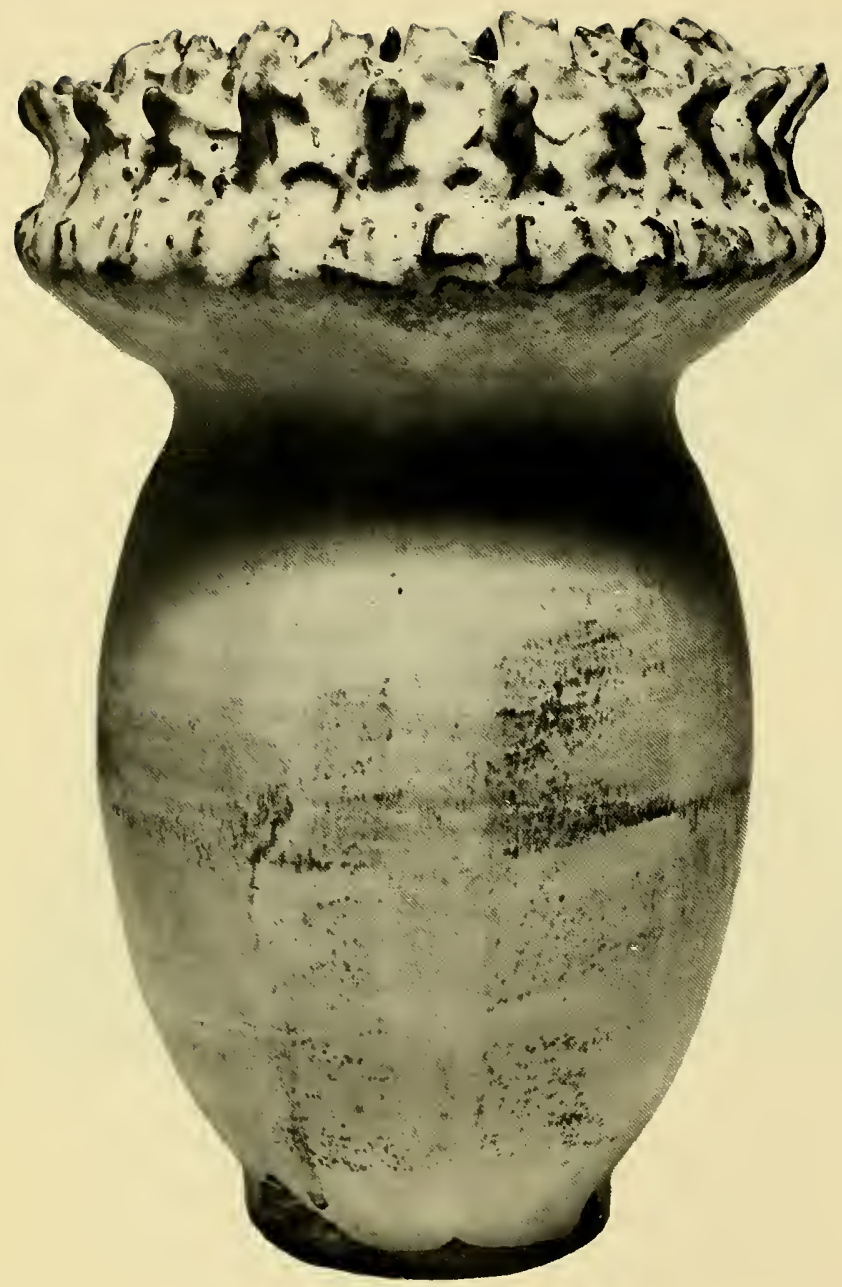

Stoneware

Purchased in memory of Georgiana L. 1955-64-1 McClellan

legend and myth; the abstracted forms and elegant theatrical gestures are clearly akin to the modern sensibility. In a literal and visual sense, the past has been dramatized in this composition; St. George is an attenuated nude of ambiguous gender, and both horse and dragon have been translated into surface pattern and composition. As a theatrical work, the sculpture does not require a suspension of disbelief, but rather an appreciation of the artistic gesture.

A work from the middle decades of the present century by the American ceramist Ka-Kwong Hui, may be considered indicative of modern trends (Figure 23). In this work, narrative has been abandoned entirely. The form is not derived from any recognizable natural object, although it suggests such an origin. The most immediately perceptible impression is one of spontaneity; the form has developed as an independent organic structure that suggests a stage in the process of growth, rather than the completion of a cycle. Textural considerationssmoothness in contrast to roughness -also encourage a tactile as well as a 
visual response. Pottery of the twentieth century, of which this work is an isolated example, has moved into a new realin of sensation and understanding that approaches the more traditional formal qualities of the fine arts.

The Cooper-Hewitt collection of contemporary pottery will continue to expand. It is impossible, of course, to document the work of every artist currently producing pottery, since the Museum collection will also continue to document the process of design in a worldwide sense. Trends in contemporary pottery are complex and divergent. Many artists are creating sculpture that may or may not refer to older traditions. The conscientious selection of new works, along with a primary concern for the quality of the objects, insures that the collections of pottery at the Cooper-Hewitt will remain a primary archive of this respected art.

\section{David Revere McFadden \\ Curator of Decorative Arts}

24.

Kurt Fishback

United States

Plate, Sunshine Bright, 1969

Earthenware

Gift of S.C. Johnson and Son, Inc. 1980-18-6

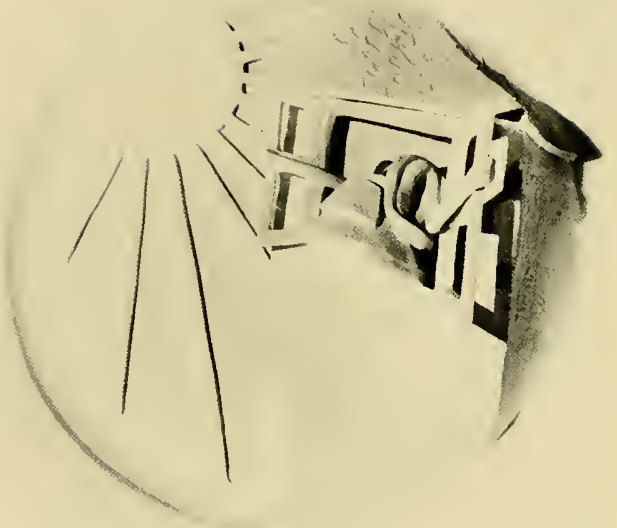




\section{Selected Bibliography}

Barber, Edwin A. The Pottery and Porcelain of the United States: An Historical Review of America's Ceramic Art from the Earliest Times to the Present Day. New York: G.P. Putnam's Sons, 1909.

Bemrose, Geoffrey. Nineteenth-Century English Pottery and Porcelain. London: Faber and Faber, 1952.

Chaffers, William. Marks and Monograms on European and Oriental Pottery and Porcelain. 2 vols. 15th rev. ed. London: W.

Reeves, 1965.

Charleston, Robert J., ed. World Ceramics. New York: McGraw-Hill, 1968.

Clark, Garth and Hughto, Margie. A Century of Ceramics in the United States, 1878-1978. New York: E.P. Dutton, 1979.

Cox, Warren E. The Book of Pottery and Porcelain. 2 vols. New York: Crown Publishers, 1944.

Cushion, J.P. Handbook of Pottery and Porcelain Marks. 4th ed. London and Boston: Faber and Faber, 1980.

Ducret, Siegfried. German Porcelain and Faience. Translated by Diana Imber. New York: Universe Books, 1962.

Frothingham, Alice Wilson. Lustreware of Spain. New York: Hispanic Society of America, 1951.

Garner, F.H. and Archer, Michael. English Delftware. 2nd ed. London: Faber and Faber, 1972.

Godden, Geoffrey A. British Pottery and Porcelain, 1780-1850. London: A. Barker, 1963.

Hetteš, Karel and Rada, Pravoslav. Modern Ceramics: Pottery and Porcelain of the World. Prague: Artis, 1965.

Honey, William B. The Ceramic Art of China and Other Countries of the Far East. London: Faber and Faber and the Hyperion

Press, 1945.

The art of the Potter. London: Faber and Faber, 1946.

English Pottery and Porcelain. Revised by R.J. Charleston. London: A.\&C. Black, 1962.

European Ceramic Art from the End of the Middle Ages to about 1815. 2nd ed. London: Faber and Faber, 1963.

Kircher, Edwin J.; Agranoff, Barbara; and Agranoff, Joseph. Rookwood: Its Golden Era of Art Pottery, 1880-1929.

Cincinnati, Ohio 1969.

Lane, Arthur. Early Islamic Pottery: Mesopotamia, Egypt and Persia. London: Faber and Faber, 1947.

Later Islamic Pottery: Persia, Syria, Egypt and Turkey. London: Faber and Faber, 1957.

French Faience. New York: Praeger Publishers, 1970.

Medley, Margaret. The Chinese Potter: A Practical History of Chinese Ceramics. Oxford: Phaidon, 1976.

Nordness, Lee. Objects USA. New York: Viking Press, 1970.

Pottery. The Smithsonian lllustrated Library of Antiques. New York: Cooper-Hewitt Museum, 1981.

Rackham, Bernard. Italian Maiolica. London: Faber and Faber, 1963.

Reilly, R. and Savage, D. The Dictionary of Wedgwood. Woodbridge, Suffolk: Antique Collectors Club, 1980.

Rose, Muriel. Artist-Potters in England. London: Faber and Faber, 1955.

Wakefield, Hugh. Victorian Pottery. London: H. Jenkins, 1962. 



\section{Cooper-Hewitt Museum}

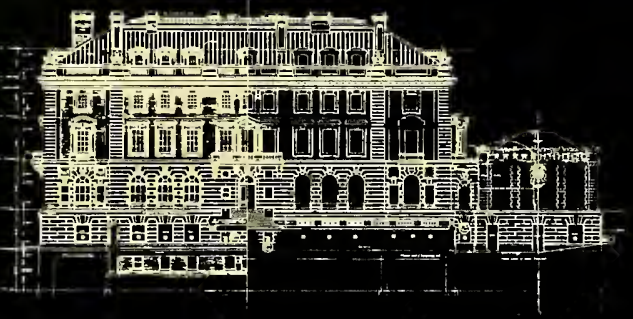





IIfIf $\sum_{i}$ ronocs

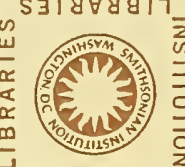

uै.
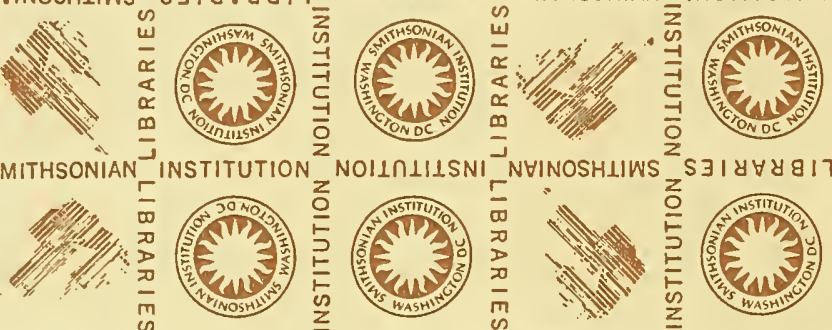

要
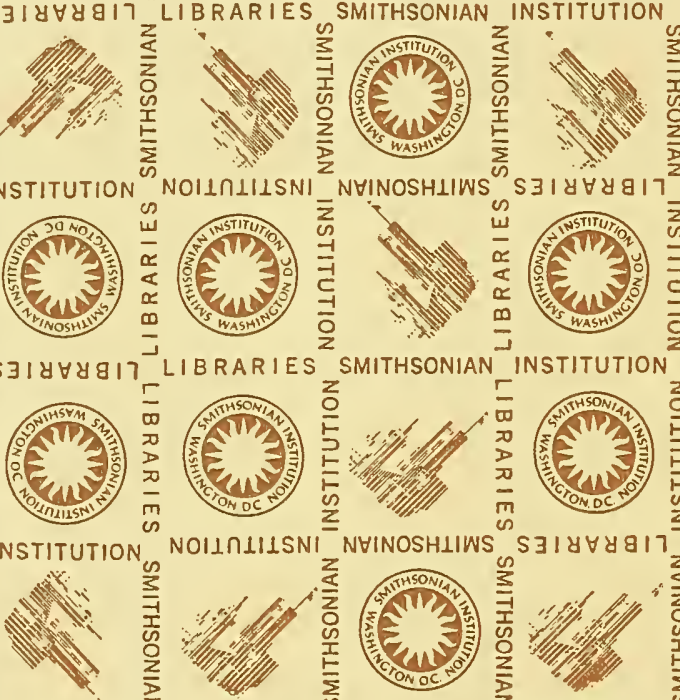

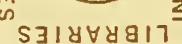

S31방 17
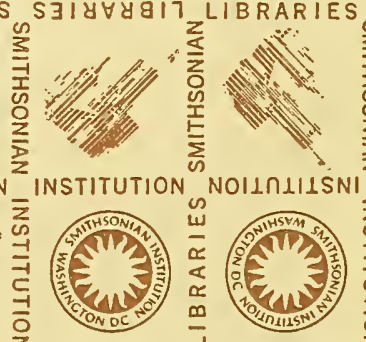
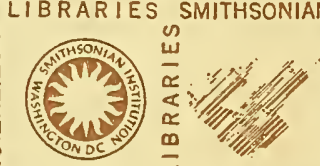
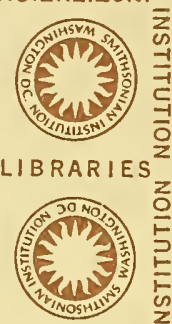
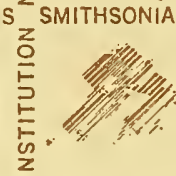

क

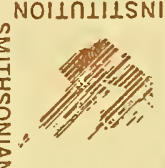

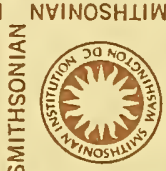

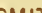

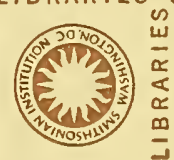
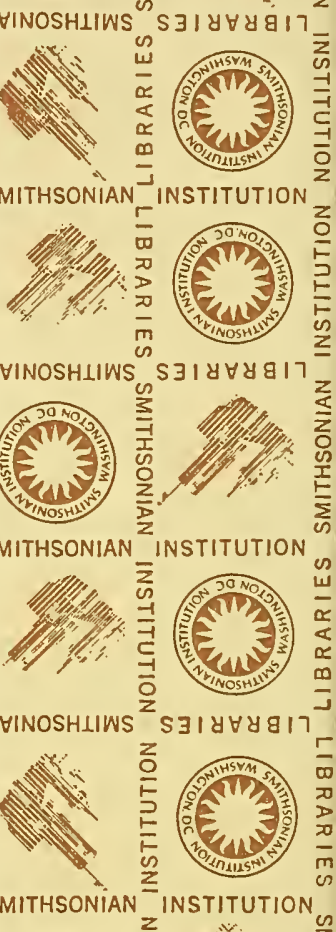

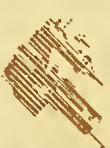

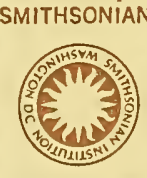
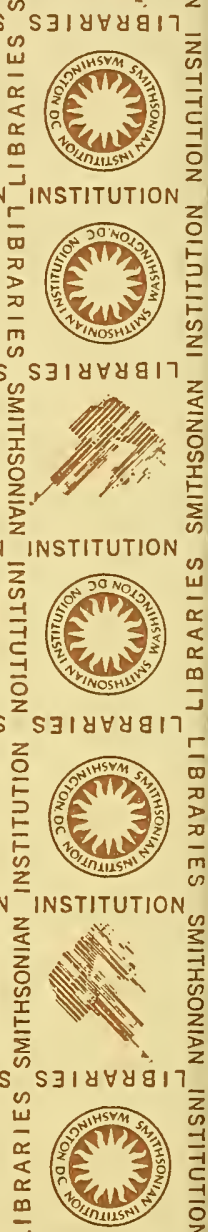

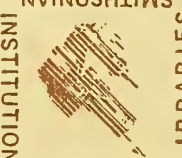

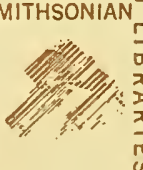

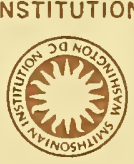

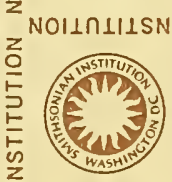

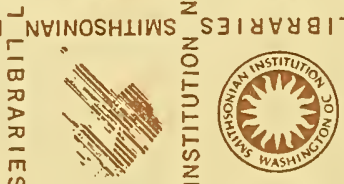

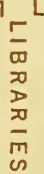

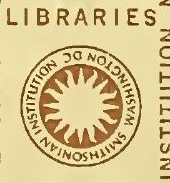


2
$y$
$z$
$z$
$y$

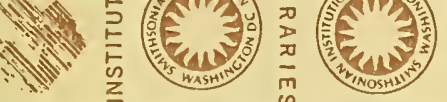

"

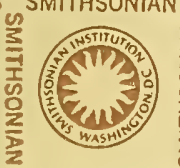

swi
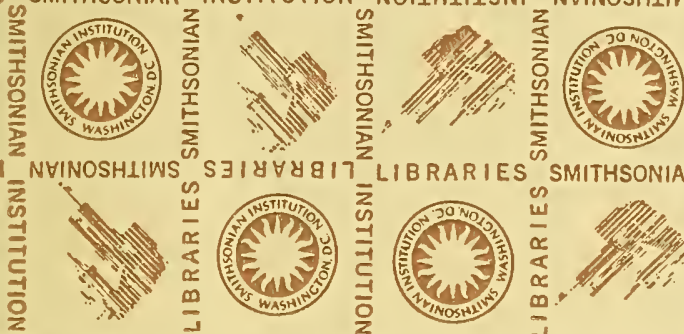

章
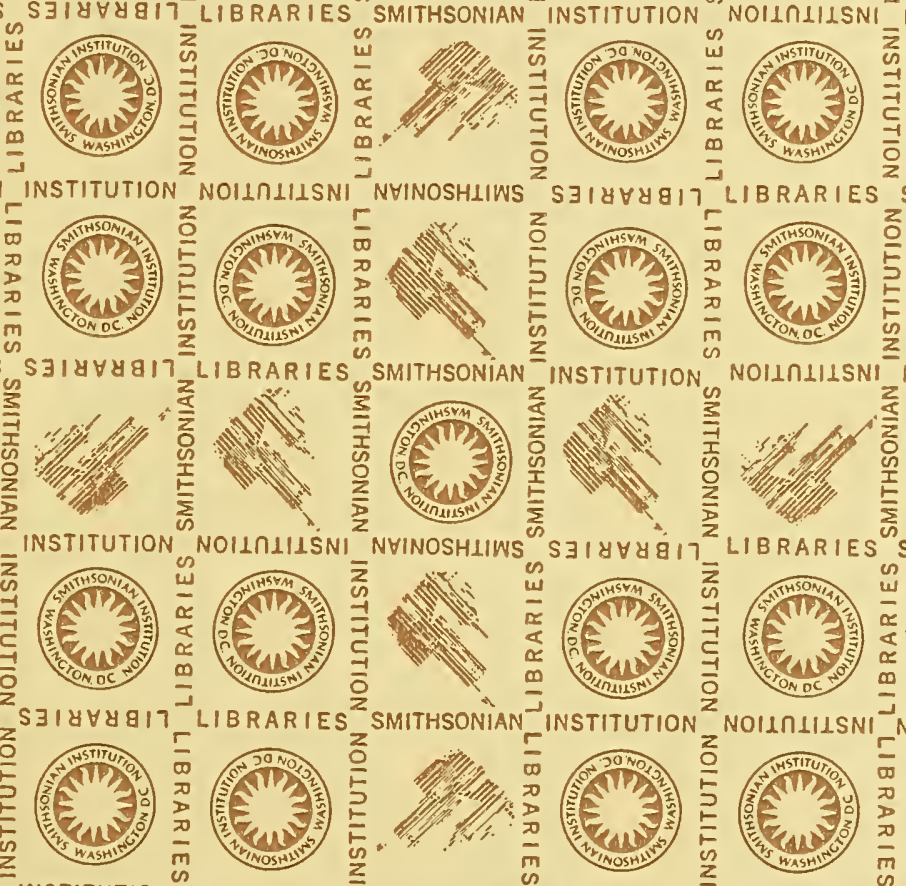

is
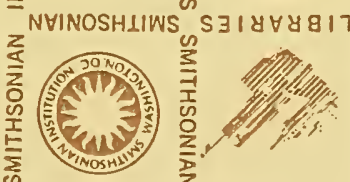

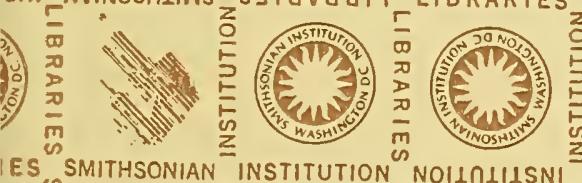

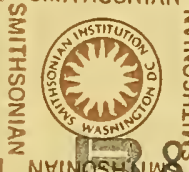

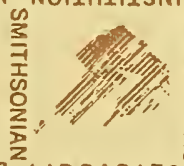

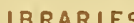

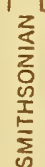

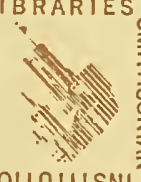

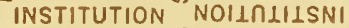

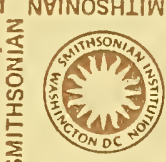

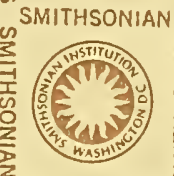

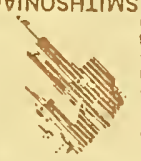

INSTITUTION
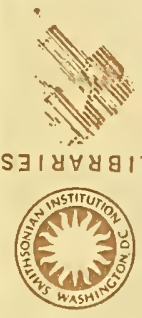

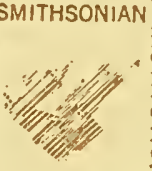

NHINOSHLIWS
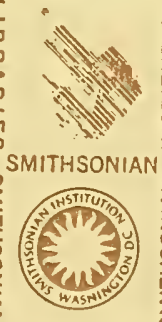
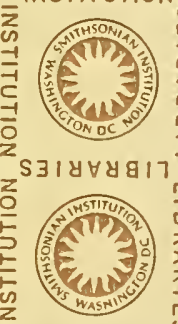

INSTITUTION

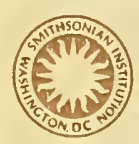

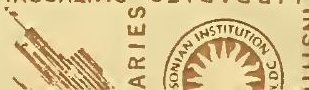


SMITHSONIAN INSTITUTION LIBRARIES 